\title{
COMERCIO EN TIEMPOS DE GUERRA: LA DISTRIBUCIÓN ANFÓRICA CARTAGINESA DURANTE EL PERÍODO BÁRQUIDA
}

\author{
TRADE IN WARTIME: CARTHAGINIAN AMPHORAE \\ DISTRIBUTION DURING THE BARCID PERIOD
}

\author{
VÍCTOR MARTÍNEZ-HAHNMÜLLER*
}

Resumen: En el presente trabajo analizamos la relación entre la guerra y el comercio por medio del estudio de las relaciones de intercambio de bienes del Imperio Cartaginés durante el último tercio del siglo III a.C. Para ello, en primer lugar, evaluamos, por medio de la información de las fuentes literarias y el registro arqueológico, las medidas que Cartago, a través de los estrategas bárquidas, promovió para incentivar el comercio en los nuevos dominios territoriales de la península ibérica. Posteriormente, revisamos las importaciones cartaginesas localizadas en los diferentes yacimientos de Iberia con el fin de definir la evolución de las relaciones comerciales entre Cartago y la península ibérica previas al desembarco de Amílcar Barca en Gadir en el año 237 a.C. A continuación, analizamos la distribución de ánforas cartaginesas de finales del siglo III a.C. en el Mediterráneo para establecer las pautas de la comercialización de productos cartagineses en este contexto y su relación con los principales eventos de la Segunda Guerra Romano-cartaginesa. Finalmente, definimos las características del comercio cartaginés en este contexto cronológico y espacial.

Palabras clave: Ánforas, Comercio, Segunda Guerra Romano-cartaginesa, Economía, Mediterráneo Occidental.

\begin{abstract}
In the current paper we will analyze the relationship between war and trade for the Carthaginian Empire during the late third century BC. In order to achieve this objective, first, we will evaluate, from literary sources and, specially, archaeological record, the different measures that Carthage promoted through barcid strategists to boost trade in the new territorial domains of the Iberian Peninsula. Moreover, we will look over the Carthaginian imports in Iberia in order to define the evolution of trade between Carthage and the Iberian Peninsula before the landing of Hamilcar Barca in Gadir in the year 237 BC. After that, we will analyze the distribution of Carthaginian amphorae during the late third century BC in the Mediterranean in order to establish the patterns for the Carthaginian trade and their relationship to the main events of the Second Punic War. Finally, we will define the main features of the Carthaginian trade in this chronological and spatial context.
\end{abstract}

Keywords: Amphorae, Trade, Second Punic War, Economy, Western Mediterranean.

* El Legado de la Antigüedad, Departamento de Geografía, Historia y Humanidades, Universidad de Almería, Cañada de San Urbano s/n, 04120-Almería. Correo-e: vmh232@ual.es 


\section{INTRODUCCIÓN}

A lo largo de la Historia Antigua, la guerra fue uno de los factores con mayores y más profundas repercusiones económicas y sociales. Los conflictos bélicos, sin menospreciar la fundamental carga política y social que pudieran albergar, fueron una forma no pacífica de adquirir bienes inexistentes en un lugar; práctica que, a menudo, coexistía con otros métodos pacíficos como el comercio (Polanyi 1994: 159). Sin embargo, más allá de su capacidad última de obtener el aprovechamiento de determinados recursos, debemos considerar la guerra como un auténtico motor económico para la Antigüedad debido a la necesidad de los ejércitos enfrentados de abastecerse de una cantidad ingente de nuevas riquezas.

La época bárquida, que abarcaría grosso modo la segunda mitad del siglo III a.C., se caracterizó por el uso prácticamente constante del conflicto armado como medio de obtención de nuevos territorios por parte de Roma y Cartago, las principales potencias mediterráneas occidentales enfrentadas. Dejando al margen los aspectos sociales y diplomáticos, los conflictos bélicos que inmiscuyeron a Cartago en este contexto cronológico tuvieron un trasfondo económico incuestionable. En este sentido, podríamos interpretar que Cartago pretendió mantener por las armas su estrategia económica en la Guerra de los Mercenarios (Loreto 1995: 48, 54 y 64), que la conquista de Iberia fue motivada por la voluntad de hacerse con los recursos agrícolas y mineros de ese territorio y que por medio de la Segunda Guerra Romano-cartaginesa, Cartago buscaba mantener y expandir su modelo de explotación económica al resto del Mediterráneo Occidental.

A pesar del unánime consenso en la literatura científica especializada en este período respecto a que la anexión cartaginesa del territorio ibérico estaba determinada principalmente por intereses económicos (Barceló 1996: 5-19; Roldán Hervás 1997: 271; Ferrer Albelda 1998: 42-44; González Wagner 1999: 263 265; López Castro 2000a: 51-61; Ferrer Maestro 2004: 439-449; Blázquez 2005: 1331-1342; 2012: 27; Prados 2007: 84-85; Bendala 2013: 53), los autores que han dedicado parte de sus líneas de investigación a los aspectos económicos del Imperio Cartaginés del último tercio del siglo III a.C. son proporcionalmente escasos. Aún menos son los que se han consagrado a estudiar otras cuestiones económicas que no sean las derivadas de los supuestos monopolios cartagineses en la explotación de determinados recursos ibéricos, como minas y salinas. El comercio en época bárquida queda relegado a los cualitativamente desiguales estudios sobre las relaciones de intercambio de algunos asentamientos que cuentan con fases de este período.

\section{LA POLÍTICA BÁRQUIDA DE INCENTIVACIÓN COMERCIAL}

Sin embargo, las relaciones de intercambio fueron imprescindibles en la estrategia económica del Imperio Cartaginés, ya que el mantenimiento de sus ejércitos dependía en gran medida de éstas y la propia presencia cartaginesa en sus dominios territoriales de éstos. Por ello, los estrategas bárquidas desarrollaron una política activa de incentivación de las actividades comerciales, tanto las que se desarrollaban por vía terrestre como las que se efectuaban por vía marítima.

En el caso del comercio terrestre, aunque la mayoría de las rutas de intercambio, si no todas, se pueden rastrear en momentos muy anteriores a la llegada de los cartagineses, fue en este contexto cuando se las elevó a una nueva categoría. La presencia de un ejército de unas dimensiones inauditas hasta el momento en el Mediterráneo Occidental provocó que los estrategas dedicaran una atención especial a los antiguos caminos naturales (Nep. Han. 3.4) con el fin de adecuarlos al avituallamiento constante de tropas, incentivar su movilidad y afianzar el control territorial cartaginés en sus zonas de dominio directo.

Para ello, los dirigentes optarían por la fundación de asentamientos de veteranos en los principales ejes de comunicación y el establecimiento de un complejo sistema de atalayas y torres que permitiría una rápida movilización de las fuerzas militares en caso de producirse un ataque. En este sentido, todas las colonias cartaginesas de veteranos no costeras que hemos podido individualizar gracias a la información numismática (Martínez Hahnmüller 2011: 299-323) presentan la característica común de situarse en lugares geoestratégicos claves, ya que se localizan en las inmediaciones del curso de los ríos más importantes y, consecuentemente, controlando las mejores vías de penetración al interior. El asentamiento de los soldados más experimentados, además de satisfacer a los propios veteranos, se constituía como un elemento disuasorio de primer orden que favorecería enormemente el comercio terrestre.

Tal efecto disuasorio se vería incrementado significativamente con la creación de un sistema de control del territorio por medio de torres y atalayas con el que poder prever los movimientos de bandidos y, en general, los ataques enemigos. Se trata de lo que Plinio el 
Viejo (NH 35.169 y 2.181) denomina torres o atalayas de Aníbal, que han generado un amplio debate historiográfico en el que no vamos a entrar en esta ocasión.

Sí señalaremos, como bien destacaba Moret (1990: 7 y 21-25), que la mayor parte de las torres ibéricas que han sido vinculadas con las torres de Aníbal mencionadas por Plinio el Viejo no cumplen las características con las que las define el enciclopedista del siglo I d.C., puesto que se trata de construcciones megalíticas y no de adobe, rasgo definitorio de las atalayas anibálicas recogidas por este autor alto-imperial. El uso de fortificaciones autóctonas por parte de los cartagineses más bien se debe relacionar con las torres descritas por Livio (29.16.6) como recintos amurallados que hacían las veces de centros de vigilancia y de defensa contra las acciones de bandidos y que, según el propio pasaje, sabemos fueron utilizadas por los cartagineses en el contexto de la Segunda Guerra Romano-cartaginesa.

Sólo la excavación arqueológica y el posterior estudio de los materiales de los recintos fortificados en altura de planta cuadrangular con zócalo de piedra y alzado de adobe documentados en el territorio ibérico nos permitirán conocer si estas estructuras se corresponden con las torres de Aníbal o con construcciones romanas posteriores como sugiere Moret (1990: 37-43). Sin embargo, a día de hoy, al menos la fortificación de El Castillarejo (Baena, Córdoba) presenta materiales datados en los últimos años del siglo III a.C.

Además, la documentación de materiales de época romana republicana y alto-imperial en estos asentamientos fortificados no contradice la información de Plinio, quien afirmaba que aún en su época algunos de estos recintos se mantenían en uso y, por lo tanto, en buenas condiciones de conservación.

Por todo ello, creemos que los bárquidas harían uso de un sistema dual en el que convivían fortificaciones ibéricas, tanto reutilizaciones de fortificaciones de épocas anteriores como construcciones ex novo de los últimos años del siglo III a.C., y las atalayas erigidas por los estrategas cartagineses.

Estas medidas obedecían principalmente, como defendieron, entre otros, Fortea y Bernier (1970), Corzo (1979), Blázquez y García-Gelabert (1991), González Wagner (1999) y Bendala (2003), a una voluntad de control de los nuevos territorios sometidos a Cartago $\mathrm{y}$, de manera complementaria, a incentivar las relaciones comerciales por tierra. Sin embargo, si tenemos en cuenta la gran rentabilidad en tiempo y costes que tenía el comercio marítimo respecto con respecto al terrestre (Hopper 1979: 52-53; Finley 1986: 30 y 154), aunque sin pretender restarle la debida importancia a este, que fue fundamental para el abastecimiento del ejército en campaña y en las estaciones en las que la navegación presentaba unos riesgos excesivos para que fuese recomendable (Principal-Ponce 1998: 205-207), es innegable que las relaciones de comercio a través del medio marítimo serían las que se desarrollasen con más asiduidad y, por lo tanto, las que acapararían la mayor parte de producciones externas. No debe extrañarnos, que la política bárquida respecto a las relaciones comerciales favoreciese, de manera especial, a aquellas que utilizaban los medios marítimos.

Una de las prácticas que Reed (2004: 48) propuso como típicas de la incentivación del comercio en el mundo antiguo fue el uso de escoltas militares para asegurar el transporte de los grandes convoyes. Sin embargo, en el ámbito crono-espacial objeto de estudio, creemos que tal protección sería innecesaria antes del inicio de la Segunda Guerra Romano-cartaginesa, ya que Cartago contaba con el control directo o con el apoyo diplomático de los principales puertos de las costas meridionales del Mediterráneo Occidental, es decir, no existirían grandes amenazas al comercio marítimo, salvo puntuales ataques piráticos, lo que, a su vez, explicaría el escaso número de barcos de guerra con que contaba el territorio ibérico cuando se rompieron las hostilidades contra Roma. El origen del conflicto armado, no obstante, pudo hacer necesario el sistema de escoltas, especialmente cuando se trataba de transportar tropas, dinero u otros recursos necesarios para abastecer a los soldados y a los colonos. El uso de las flotas como escoltas militares de los grandes convoyes comerciales y de refuerzos militares, explicaría la escasez de operaciones bélicas en el frente marítimo en el transcurso del conflicto armado tanto por el bando cartaginés como por el romano.

En realidad, el único enfrentamiento naval se produjo en el año 217 a.C. en las inmediaciones del río Ebro (Pol. 3. 95-96; Liv. 20.1-9; 22.19). Allí, las 35 naves de Cneo Escipión vencieron a las 40 del navarca Amílcar o Himilcón al cogerlas por sorpresa, logrando capturar 25 naves antes de la retirada cartaginesa. Tras la victoria romana, las narraciones de Polibio y Tito Livio divergen. Por un lado, el autor megalopolitano sostiene que la respuesta cartaginesa a la derrota fue la preparación de una flota de 70 navíos con la cual se dedicó a hacer razzias en la costa sarda y pisana, hasta que Roma envió una escuadra de 120 barcos que obligó a la armada cartaginesa a regresar, presumiblemente, a Iberia. La versión del autor paduano, en cambio, nos presenta cómo tras la victoria Roma progresó en su avance conquistando Osuna, ciudad que no se ha localizado 
pero que a partir de esta narración se debe situar entre Cartagena y el río Ebro. Posteriormente, devastaría el hinterland de Qart Hadasht e Iboshim, logrando que las poblaciones de las Islas Baleares se pasaran al bando romano, y llevaría la guerra hasta el Saltus Castulonensis, obligando a Asdrúbal a retirarse a Lusitania.

Como vemos, se trata de demasiadas acciones de guerra para el estrecho lapso de tiempo que separa la victoria romana en la batalla naval del Ebro y el desembarco de Publio Escipión con refuerzos en Tarraco (Pol. 3.97.2-4; Liv. 22.22.1-3) que, además, contradice la afirmación expresa de Polibio respecto a que los romanos no se atrevieron a cruzar el río Ebro hasta que los hermanos Escipiones unieron sus fuerzas (Pol. 3.97.5-8; App. Ib.15). En este sentido, creemos que la narración de Livio sobre las consecuencias de la batalla del Ebro debe ser interpretada como una invención del autor latino destinada a ensalzar las victorias romanas en un momento en el que la guerra se decantaba peligrosamente a favor del bando cartaginés en el frente itálico (García Riaza y Sánchez León 2000: 103; Costa 2000: 70-71). Por ello, si nos centramos en la versión de Polibio, a pesar de los importantes problemas internos que acarreó la derrota cartaginesa (López Castro 2000a: 55-56), esta no fue tan severa en el plano militar, ya que antes de la llegada de Publio Escipión a Iberia los cartagineses pudieron rehacer su flota destacada en este territorio hasta alcanzar las 70 naves, 30 más que las destacadas en el enfrentamiento mencionado. Según las fuentes clásicas, ya no se producirían más batallas navales directas, por lo que debemos suponer que las embarcaciones se utilizarían con fines defensivos tales como la realización de tareas de escolta a los principales convoyes de tropas, dinero y avituallamiento y la vigilancia de las costas para disuadir las posibles incursiones romanas en los territorios bajo dominio cartaginés.

Además de mantener la seguridad en las distintas rutas de comercio, el Imperio Cartaginés podría recurrir a otros mecanismos para incentivar el comercio como la creación de infraestructuras portuarias, el ofrecimiento de prerrogativas especiales a los comerciantes, especialmente a los extranjeros, y la voluntad de garantizar la agilidad y la igualdad legal en las transacciones (Hopper 1979: 58-59 y 108; Descat 1994: 21 26; Reed 2004: 43-49).

En el caso que nos ocupa, la mayor parte de las ciudades costeras en el área bajo dominio cartaginés contarían con sus oportunas estructuras portuarias debido a su larga tradición comercial: estas serían desde simples fondeaderos naturales a complejas construcciones destinadas al almacenamiento de mercancías y el mantenimiento de los navíos de transporte. Desgraciadamente, la evidencia arqueológica al respecto es muy deficiente como resultado tanto de la evolución de la línea de costa como, sobre todo, del acelerado proceso urbanístico de los últimos decenios, que ha alterado la mayoría de las zonas litorales. En realidad, solo en el caso de Qart Hadasht de Iberia (Más 1998: 85; Berrocal 1998: 101-102 y 108-114) o en el de su homónima norteafricana (Hurst 1983: 604 y 609-610) se han podido documentar estructuras portuarias de gran magnitud cuya creación, no obstante, no ha sido datada con exactitud. En el estado actual de nuestros conocimientos es demasiado aventurado decantarse hacia la posibilidad de que la monumentalización promovida por los bárquidas en sus dominios supusiera la creación, adaptación o mejora de sus puertos, pero dada la importancia que tuvo el comercio para el Imperio Cartaginés no sería muy inverosímil. De hecho, en el interior de las murallas de las ciudades fundadas ex novo y de aquellas que fueron objeto de un proyecto urbanístico monumental por parte de los cartagineses se ha constatado la existencia de espacios cuyas características estructurales permiten interpretarlos como almacenes: es el caso de las torres VI y VIII de la muralla de finales del siglo III a.C. del Tossal de Manises (Olcina et al. 2010: 236-237), de las casernas de la muralla monumental de Carteia (Roldán Gómez et al. 2006: 301310), del recinto murario de época bárquida de Castillo de Doña Blanca (Barrionuevo et al. 1999: 117-119) y de la muralla de Qart Hadasht (Martín Camino y Belmonte 1993: 162-163; Marín 1997-1998: 125), donde recientemente se han documentado también cisternas para la acumulación de líquidos en el interior del trazado murario (Noguera et al. 2011-2012: 483-494 y 501). Aunque estos espacios estarían destinados de manera prácticamente exclusiva a recolectar los recursos reservados a abastecer a los ejércitos acuartelados en estas ciudades, creemos que otros espacios similares se construirían, o se ampliarían en caso de que existieran ya, en las cercanías de fondeaderos o puertos con el fin de agilizar e estimular el resto de actividades comerciales.

En cuanto a la incentivación del comercio por medio de la concesión de prerrogativas o ventajas legales a los mercaderes extranjeros, contamos con algunos testimonios en la epigrafía cartaginesa del siglo III a.C. que pueden ser interpretados en este sentido. Así, entre el repertorio epigráfico cartaginés se ha constatado la existencia de al menos tres comerciantes que, a pesar de presentar antropónimos o ancestros con nombres 
que no son propios del ámbito fenicio (CIS I, 3885, 3889 y 5907), celebran el rito del tofet y, por lo tanto, hacen uso de atribuciones religiosas propias de los ciudadanos cartagineses (Manfredi 2003: 409).

A diferencia de lo que sucede en el mundo griego o latino, vemos cómo en Cartago la profesión de comerciante gozaba de cierto prestigio social. Más allá del propio estereotipo, los comerciantes son los segundos profesionales mejor representados en la epigrafía cartaginesa, lo que demuestra, consecuentemente, que el comercio fue una importante fuente de ingresos para la élite del Imperio Cartaginés. Fruto de este particular interés debemos entender las facilidades que, tradicionalmente, Cartago ofrecía a la actividad comercial por parte de mercaderes extranjeros. Un ejemplo evidente de esta actitud lo encontramos en las cláusulas del Segundo Tratado Romano-cartaginés del año 348 a.C. (Pol. 3.24.12), por las cuales se ofrecían a los comerciantes romanos que pretendiesen llevar a cabo sus relaciones de intercambio en Cartago unas condiciones equivalentes a las de los propios ciudadanos cartagineses (Scardigli 1991: 115-116). Consideramos que tales cláusulas se aplicarían también a las demás ciudades que mantenían pactos de alianza con Cartago y, por lo tanto, en el contexto objeto de estudio, a los principales puertos de comercio meridionales del Mediterráneo Occidental.

Junto a los tratados comerciales, el estado cartaginés contaba con una serie de magistrados encargados de controlar la equidad y legalidad de las transacciones que se desarrollaban en los puertos abiertos al comercio internacional (Principal-Ponce 1998: 193; Ruiz Cabrero 2009: 17-18), tal como sucedía en el ámbito griego (Scardagli 1991: 74). Nos referimos al spr, escriba o secretario, equivalente al $\gamma \rho \alpha \mu \mu \alpha \tau \varepsilon v ́ \varsigma$ heleno, encomendado de registrar los contratos comerciales; los $m h \breve{s} b m$, contables, relacionados con el control de las actividades financieras y mercantiles y que disponían de la autoridad para sancionar infracciones; y los $m h z m$, inspectores de mercado, documentados hasta el momento de manera exclusiva en inscripciones neopúnicas y que se interpretan como aediles romanos.

\section{LA EVOLUCIÓN DEL COMERCIO CARTAGINÉS EN EL MEDITERRÁNEO OCCIDENTAL}

Algunos de estos incentivos, prerrogativas o construcciones no fueron exclusivos del último tercio del siglo III a.C., ya que Cartago había iniciado siglos atrás su expansión económica en el Mediterráneo Central y
Occidental. Si tenemos en cuenta que el comercio en la Antigüedad se fundamentaría en el intercambio de metales, objetos metálicos, productos alimenticios y esclavos, el mejor testigo arqueológico para evaluar las relaciones comerciales de este período son los restos anfóricos, ya que se trata de uno de los testimonios directos más numerosos del comercio antiguo (López Castro 2000b: 123). En efecto, tal y como señala Carretero (2007: 4), el ánfora nos permite conocer detalles de algunos aspectos socio-económicos de un asentamiento y su región en un momento determinado y sus interacciones con otras formas sociales. Aunque el desigual desarrollo de la actividad arqueológica y de las consiguientes publicaciones en las distintas zonas objeto de estudio no permite analizar en profundidad el comercio cartaginés en el Mediterráneo Occidental para estos momentos, la información disponible es suficiente para esbozar la evolución del mismo.

Partiendo de esta premisa, el comercio entre Cartago e Iberia se puede retrotraer hasta, al menos, el siglo VIII a.C. como demuestra la documentación de ánforas de los tipos 3.1.1.1 y 3.1.1.2 de Ramón en el estrato I-II de Toscanos (Málaga), en la Plaza de las Monjas y C/Méndez Núñez de Huelva, en Morro de Mezquitilla (Málaga), en Castillo de Doña Blanca (Cádiz) y Sa Caleta (Islas Baleares) (Docter 1994: 127-133; López Castro 2000b: 125; Ramón 2006:76-77 y 79; 2008: 238-239). Junto a estas ánforas también se han documentado otras importaciones cartaginesas propias de la vajilla de mesa y cocina en asentamientos como el ya mencionado de Toscanos y La Fonteta (Alicante) (Ramón 2006: 77-78; 2008: 239). La escasa representación numérica y espacial de los productos de Cartago en Iberia respondería a una fase de toma de contacto, en la que los comerciantes aprovecharían las escalas en los asentamientos del Mediterráneo central y de los circuitos comerciales que unían el Mediterráneo oriental y occidental, para abastecerse con algunas producciones procedentes de la colonia tiria fundada por Dido.

La tendencia respecto al comercio de estos productos norteafricanos se mantiene en la centuria siguiente, ya que aunque el número total de yacimientos que presentan ánforas cartaginesas de este período, concretamente los tipos 3.1.1.2 y 2.1.1.2, se reduce considerablemente, su aparición aumenta proporcionalmente como demuestran los casos de Sa Caleta (Ramón 2006: 79; 2008: 240) y Toscanos (Docter 1994: 127-133), en los que se han realizado estudios estadísticos más completos. Este pobre panorama, que en parte es fruto de la escasez de publicaciones completas de materiales, se completaría con otras importaciones de 
vajilla cartaginesa como las documentadas en La Fonteta, Penya Negra (Alicante) y Sa Caleta (Ramón 2006: 78; 2008: 239-240) y la documentación de un ánfora en Abdera (Almería).

Durante el siglo VI a.C., Cartago se consolida como potencia político-económica de primer orden en el Mediterráneo central y las antiguas colonias semitas del Extremo Occidente se afianzan al constituirse como auténticas ciudades-estado (López Castro 2003). Estos procesos sincrónicos tuvieron importantes consecuencias sociales y económicas. Una de ellas fue el significativo incremento de las relaciones comerciales entre Cartago y el Extremo Occidente, consolidando de esta manera una ruta comercial que con el paso del tiempo se tornaría prioritaria. Los recipientes de transporte cartaginés de este momento, los tipos 1.3.2.1 y 2.1.1.2 de Ramón, aparecen en gran número de yacimientos del Mediterráneo Occidental, aunque salvo en el caso de Toscanos (Docter 1994: 127-133) y Emporion (Gerona) (Ramón 2006: 78-79; 2008: 239), no se ha realizado ningún tipo de análisis estadístico. Mientras que el tipo 1.3.2.1 solo se ha documentado en Arlés (Bocas del Ródano, Francia), Saint-Pierre-les-Martigues (Provenza-Alpes-Costa Azul, Francia) y en la avenida del 3 de Agosto de Huelva (Ramón 2006: 78-79; Ramón 2008: 240), el tipo 2.1.1.2, por su parte, ha sido constatado en contextos del siglo VI a.C. como los de Les Andalouses (Orán), Rachgoun (Orán) y Mersa Madak (Orán) en la costa argelina; los de Castillo de Doña Blanca y Cádiz en el área de influencia gadirita; los de Toscanos y el puerto de Toscanos en la desembocadura del río Vélez; el del pecio del Bajo de la Campana de Murcia; el de Sa Punta de Tur Esquerrer en el hinterland de Iboshim; el de Torre la Sal en la actual provincia de Castellón; los de la Moleta del Remei y Aldovesta de la actual provincia de Tarragona; el de Emporion; y los de Marsella y Saint Balese (Bocas del Ródano, Francia) en el área bajo el dominio de la ciudad griega de Massalia (López Castro 2000b: 125; Mederos y Ruiz Cabrero 2004: 268; Ramón 2006: 78-79; 2008: 240). Junto con las ánforas, Cartago también importó vajilla de este período tanto en Coria del Río (Sevilla) como en la necrópolis de Puig des Molins y en el santuario de Illa Plana (Ibiza, Islas Baleares).

Esta disposición al alza del comercio cartaginés en el Mediterráneo occidental durante el siglo VI a.C. se interrumpe de manera brusca, incluso total, durante la primera mitad del siglo V a.C. Aunque tal cambio radical pudiera relacionarse, en cierta medida, con el cambio de la política internacional cartaginesa que comportó una presencia más directa en Sicilia y el inicio de los conflictos greco-cartagineses por el control de la isla, compartimos la opinión de López Castro (2000b: 126-130) respecto a que el vacío obedece, sobre todo, a la ausencia de excavaciones y publicaciones de yacimientos de este periodo.

A finales del siglo $\mathrm{V}$ a.C., las producciones cartaginesas reaparecen tímidamente en la península ibérica por medio de las ánforas T-4.1.1.2 documentadas en Emporion, en la isla de Ibiza, tanto en San Antonio como en la necrópolis del Puig des Molins, en Cerro del Prado (Cádiz) y en Castillo de Doña Blanca (López Castro 2000b: 130; Ramón 2006: 79). En los pocos casos en los que se han hecho estudios estadísticos, en Emporion y en los yacimientos ibicencos, los porcentajes de las ánforas cartaginesas respecto al resto de importaciones son especialmente bajos (Ramón 2006: 79).

Como consecuencia de la creciente hegemonía económica y política de Cartago en el Mediterráneo central, este pobre panorama comercial cambiaría de manera radical a lo largo del siglo IV a.C. y primera mitad del siglo III a.C. cuando las importaciones anfóricas cartaginesas se generalizan en el Mediterráneo occidental pasando de los 5 yacimientos de la segunda mitad del siglo V a.C. a una veintena en la centuria siguiente (Ramón 1995; López Castro 2000b:131-134). Sin embargo, los hallazgos de las distintas ánforas producidas en Cartago en este contexto, correspondientes a los tipos 4.2.1.2, 4.2.1.5, 4.2.1.7 y 7.1.2.1 de Ramón, son cuantitativamente reducidos y se localizan, preferentemente, en la mitad septentrional del Mediterráneo occidental. Esta última característica podría interpretarse como una preferencia cartaginesa por la ruta que a través de las islas del Mediterráneo central y las Islas Baleares llegaba a la península ibérica. No obstante, no hay que descartar que, de nuevo, la escasez de hallazgos en el sector meridional del Mediterráneo occidental obedezca a una desigual calidad y desarrollo de la actividad arqueológica.

\section{EL COMERCIO DE ÁNFORAS CARTAGINESAS A FINALES DEL SIGLO III A.C.}

Si durante el siglo IV y la primera mitad de la centuria siguiente los productos cartagineses recuperaban e incluso aumentaban su presencia en los puertos de comercio del Mediterráneo occidental, la expansión militar cartaginesa de finales del siglo III a.C. propició que sus exportaciones se extendieran y se intensificaran de tal manera que se constituyeron como importaciones habituales en muchos asentamientos, especialmente 


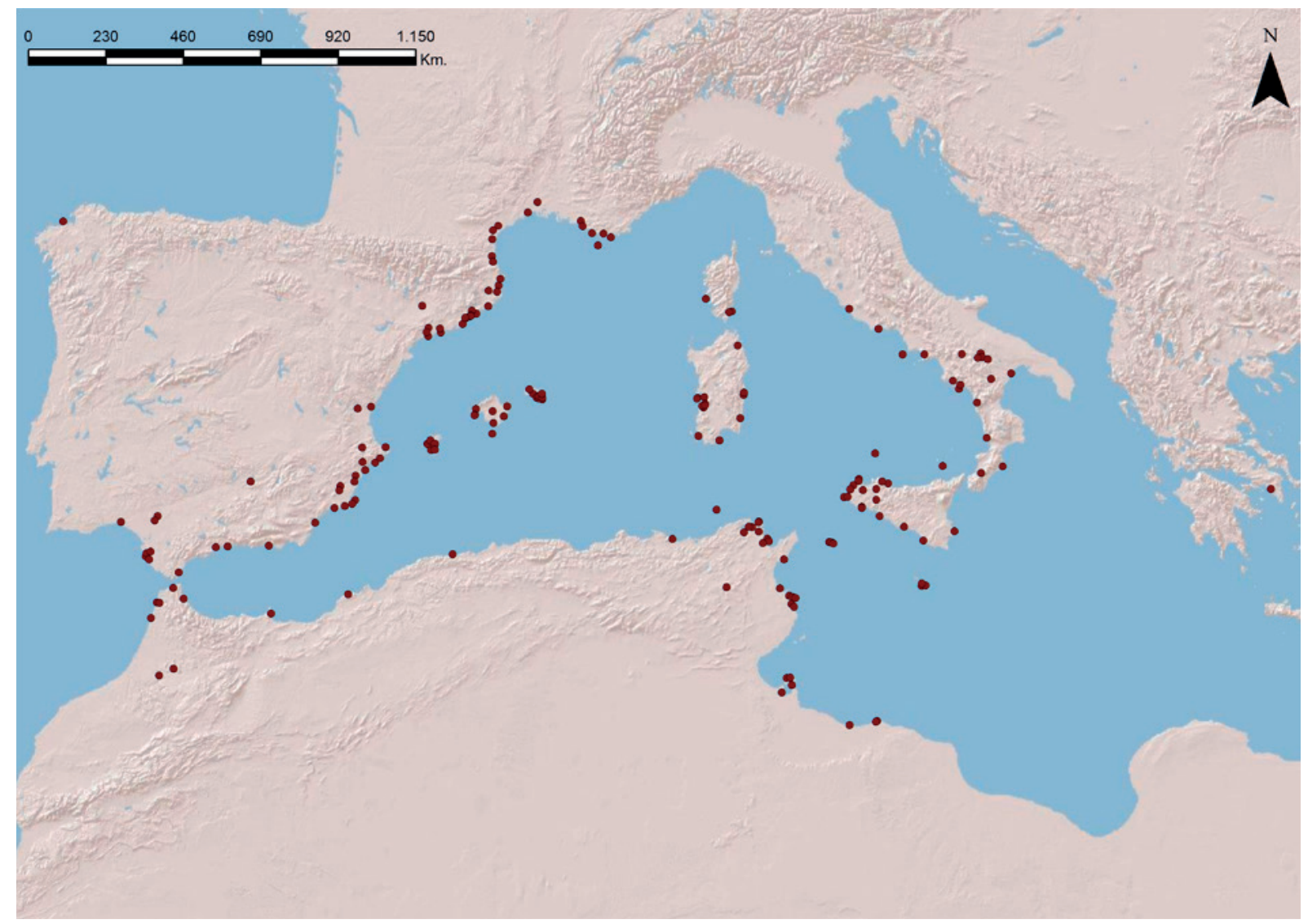

Figura 1. Mapa con la distribución de ánforas cartaginesas.

costeros, del Mediterráneo central y occidental. Al depender enteramente del creciente registro arqueológico, la información de la que disponemos sobre la comercialización de estos recipientes es muy parcial. Además, la calidad variable de los diferentes estudios de los materiales arqueológicos recuperados en los yacimientos analizados también ha alterado a la baja los resultados presentados aquí: es demasiado frecuente, especialmente en publicaciones de las primeras décadas de la segunda mitad del siglo XX, encontrar alusiones a ánforas cartaginesas sin establecer el número de individuos documentados.

Sin embargo, y a pesar de todas estas limitaciones, que esperamos se vayan superando con el tiempo, la información disponible sobre el comercio cartaginés de finales del siglo III a.C. es lo suficientemente extensa como para definir sus principales características, no solo a nivel general, sino también a nivel regional. En efecto, las más de 1.250 ánforas cartaginesas recuperadas en los casi 200 yacimientos repartidos por todo el Mediterráneo y la franja costera atlántica de la península ibérica y el norte de África nos permiten tener una visión general, aunque relativamente sesgada, del alcance del comercio cartaginés en época bárquida. (Fig. 1).

Como era de esperar, las exportaciones cartaginesas se encuentran pasadas sus fronteras territoriales y sus áreas de influencia $\mathrm{y}$, aunque no tienen que responder a un comercio directo de comerciantes cartagineses, sí demuestra la fama de los alimentos transportados en estos envases anfóricos por todo el Mediterráneo. En este sentido, por ejemplo, el límite occidental se situaría, de momento, en el ejemplar de T-5.2.3.1 documentado en el litoral de La Coruña (Domínguez Pérez 2006: 150), lo que hace presuponer que en un futuro se documenten hallazgos aislados de semejante índole en otras zonas de la actual costa portuguesa o gallega e, incluso, más al norte si eran el resultado de las rutas comerciales que unían las islas británicas con el estrecho de Gibraltar. El límite oriental, por su parte, también aparece particularmente alejado del área de influencia directa cartaginesa: se trata de un ánfora del tipo T-7.2.1.1 documentada en Atenas (Ramón 1995) que demuestra que 


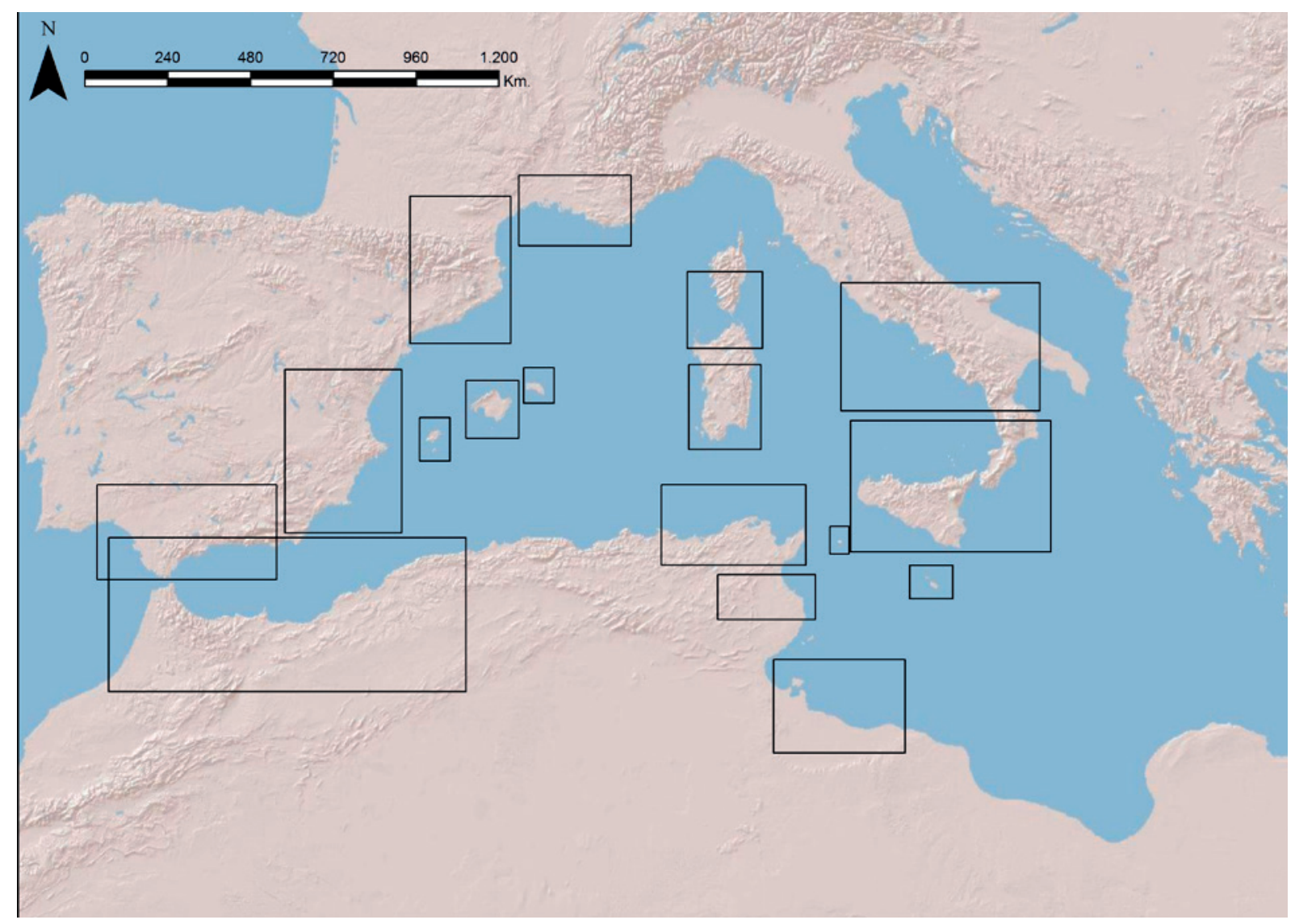

Figura 2. Principales áreas de concentración de ánforas cartaginesas y sus correspondientes mapas de detalle.

la ruta comercial entre Grecia y Cartago, iniciada con la propia fundación de la Ciudad Nueva, se mantenía en activo a finales del siglo III a.C. A diferencia de lo visto hasta el momento, los límites meridional y septentrional no están representados por hallazgos arqueológicos aislados, sino que se enmarcan en zonas en las que las importaciones cartaginesas tienen una presencia destacada. Este es el caso del ejemplar más septentrional, un ánfora T-5.2.3.1 aparecida en el asentamiento galo de La Chazette (Congénies, Gard, Francia), localizado en las cercanías de la colonia griega de Lattara (Lattes, Hérault, Francia), donde, a su vez, se han recuperado un mínimo de 9 ánforas cartaginesas (Ramón 1995; Py et al. 2001). Finalmente, la importación cartaginesa más meridional constatada hasta la fecha se la disputan por el este el asentamiento cartaginés de $\mathrm{Sa}$ bratha (Șabrãtah, Libia), con 2 ánforas del grupo 5 y una del grupo 7 de la tipología de Ramón (1995), y por el oeste el yacimiento rural mauritano de Rirha (Sidi Slimane, Marruecos), donde se documentó un ánfora del tipo T-7.4.2.1 (Bridoux 2007). (Fig. 2).
Una vez establecidos los límites que alcanzó el comercio cartaginés a finales del siglo III a.C., vamos a desglosar las características que definieron ese comercio en sus principales áreas de influencia. No obstante, el mencionado desarrollo desigual de la investigación en cada una de las zonas, la escasez de publicaciones en algunos territorios y nuestra mayor familiaridad con la bibliografía y los materiales de la península ibérica y las islas Baleares, pueden provocar comportamientos anómalos en el mapa general de exportaciones cartaginesas. Sin embargo, es cierto que estas anomalías encajan a la perfección con la realidad histórica que comportó la expansión territorial del Imperio Cartaginés a finales del siglo III a.C. y la posterior Segunda Guerra Romano-cartaginesa. (Fig. 3).

En este sentido, la característica definitoria del comercio cartaginés en la península ibérica es la necesidad de abastecer a los grandes ejércitos de Iberia que, a partir de la información de Diodoro Sículo (20.12 y 25.10.1 y 2), Polibio (3.35.2-3 y 7) y Tito Livio (21.23.1), podemos estimar estaban conformados 
Figura 3. Gráfico con la concentración de ánforas cartaginesas en las diferentes áreas objeto de

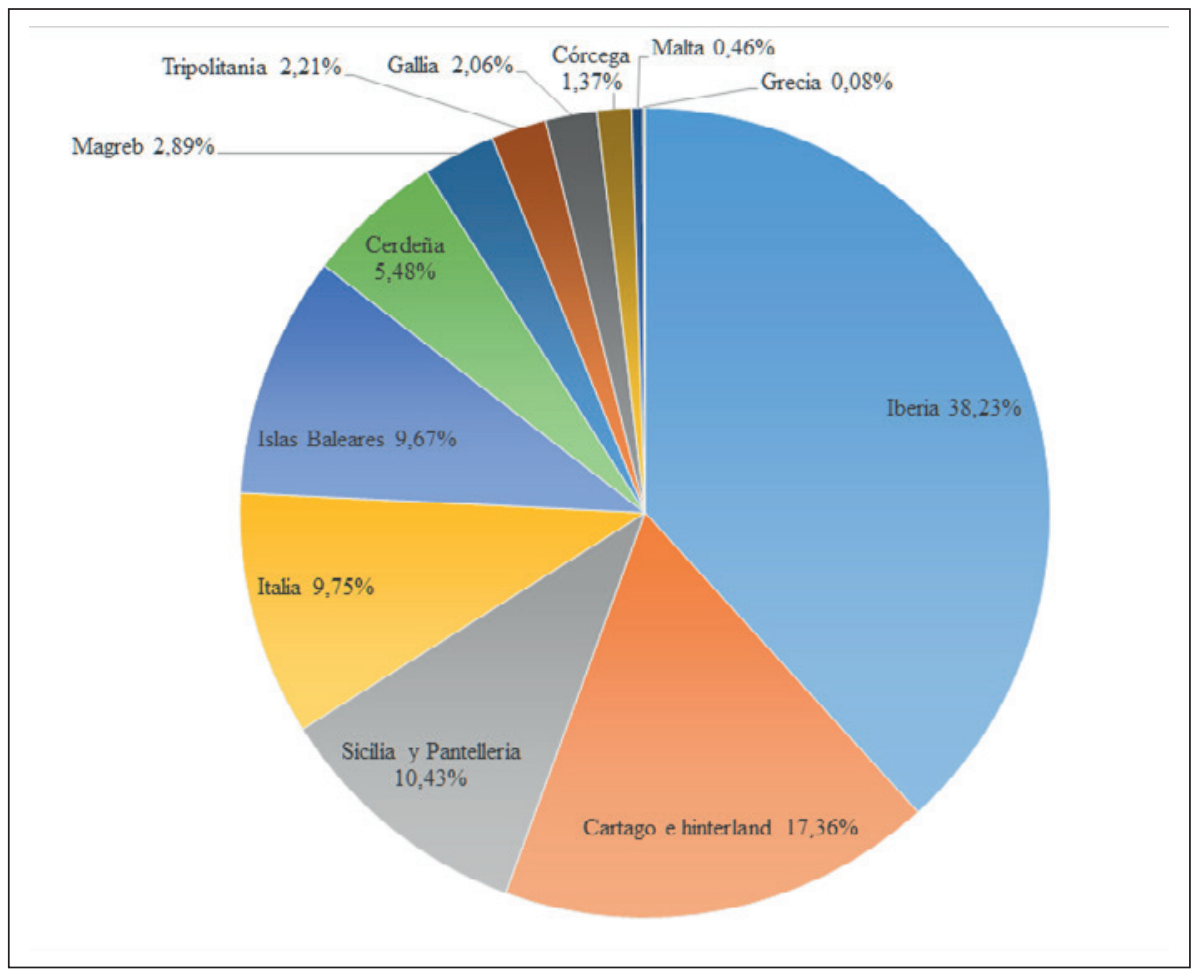

por entre un mínimo de 40.000 soldados para las fuerzas expedicionarias de Amílcar Barca y un máximo de poco más de 100.000 efectivos en el inicio de la Segunda Guerra Romano-cartaginesa, siempre entre caballería e infantería. Este hecho y el constituirse el frente ibérico como uno de los más activos de la guerra contra Roma justifican a la perfección la presencia en esta región de más de una tercera parte del total de ánforas procedentes de los distintos talleres alfareros controlados por Cartago. Es tan elevado el número de producciones cartaginesas en territorio ibérico, que no solo queda atestiguada su importancia para los planes de los estrategas al mando de las fuerzas militares de Cartago, sino que nos hace plantearnos la posibilidad de que una parte de las ánforas y, por lo tanto, sus contenidos, fuesen producidas en los nuevos dominios cartagineses de la zona. Podríamos vincular esta hipótesis más directamente con el tipo 5.2.3.1 de la clasificación de Ramón (1995), ya que más de la mitad de los más de 500 individuos documentados proceden de contextos arqueológicos de la península ibérica, aunque, por ahora, los únicos talleres encargados de realizar esta forma que se han localizado son los alfares de Cartago (Túnez) (Sáez Romero et al. 2004: 214-217) y de Utica (Bizerta) (Maraoui Telmini y Bouhlel 2011), ambos en Túnez. (Fig. 4).
Asimismo, junto con el predominio cuantitativo de la comercialización de productos alimenticios cartagineses, Iberia cuenta con una superioridad cualitativa, ya que del extenso repertorio formal de ánforas exportadas de los territorios norteafricanos del Imperio Cartaginés, se han constatado ejemplares pertenecientes a todos los grandes grupos formales y 14 de los 18 tipos anfóricos concretos de este momento. Tras la indiscutible preponderancia del grupo 5, con los tipos 5.2.3.1 y 5.2.3.2, posiblemente destinados al transporte de vino por su forma cilíndrica y la documentación de resina en alguno de sus ejemplares (Ramón 1995: 264 y 266), el grupo 7 es el mejor representado en los contextos de finales del siglo III a.C. de la península ibérica, alcanzando casi un $25 \%$ del total. Caracterizado también por su forma cilíndrica, aunque con bordes exvasados y pivote a modo de fondo, su contenido, a falta de estudios químicos más precisos, se ha relacionado de manera hipotética tanto con el transporte de salazones de pescado como de vino, debido, por un lado, a su parecido formal con algunas ánforas de salazones gaditanas y, por otra parte, por la presencia de resina en algunos ejemplares de los tipos T-7.4.2.1 y T-7.4.3.1 (Ramón 1995: 264-266). En Iberia, las formas más representadas de este grupo se corresponden con el tipo T-7.2.1.1 y la ya aludida forma T-7.4.2.1. 


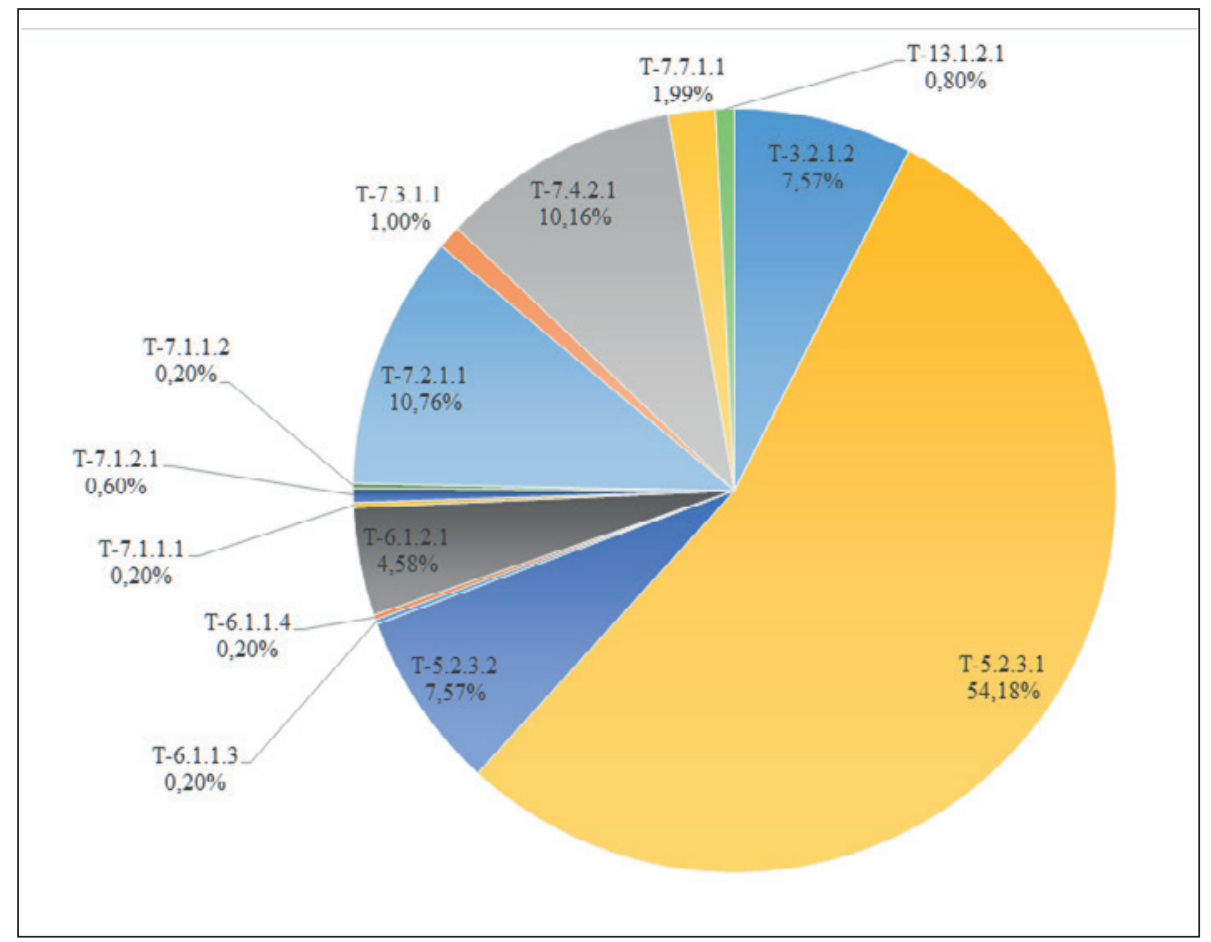

Figura 4. Gráfico con la relación de los diferentes tipos anfóricos cartagineses documentados en la península ibérica.

El tercer grupo mejor constatado, aunque con un porcentaje inferior al $8 \%$ del total de exportaciones cartaginesas para Iberia, es el tipo 3.2.1.2 (Ramón 1995: 183; Martín Camino y Roldán Bernal 1994), único representante del grupo 3 documentado en la península ibérica. Es un ánfora de tamaño pequeño o mediano de tendencia ovoide y fondo redondeado sobre cuyo contenido no tenemos ninguna información concreta.

El cuarto conjunto formal con una mayor presencia estadística en Iberia es el conformado por las ánforas del grupo 6 de Ramón, que suponen menos de un 5\% del total de ánforas cartaginesas. Este grupo minoritario está conformado por ánforas de tamaño medio de perfil ovoide y alargado y fondo redondeado (Ramón 1995: 201-202) de las que tampoco contamos con ningún indicio o análisis sobre su contenido.

La forma T-13.1.2.1 (Ramón 1995: 241-242), con una representación inferior al 1\%, conforma el grupo de ánforas cartaginesas que menos ha sido documentado en Iberia. Se trata de un ánfora de cuerpo bicónico $\mathrm{y}$ fondo redondeado de tamaño pequeño, uno de cuyos rasgos formales más característicos es la presencia de asas helicoidales, pero cuyo contenido también nos resulta desconocido. (Fig. 5).

En cuanto a la localización espacial de las ánforas cartaginesas en la península ibérica, siguiendo las tendencias comerciales del momento, se concentran en los núcleos costeros, aunque hay notables excepciones como Giribaile (Vilches, Jaén) y Molí d'Espígol (Tornabous, Lérida), a más de $250 \mathrm{~km}$ y casi $100 \mathrm{~km}$ de la costa, respectivamente. Por otro lado, no existen grandes diferencias ni en la cantidad de ánforas documentadas ni en el número de yacimientos entre las distintas zonas en las que hemos dividido la península ibérica para facilitar la visualización de la información. Sin embargo, sí que apreciamos una especial concentración en las áreas en las que la Segunda Guerra Romano-cartaginesa tuvo una mayor incidencia, tal y como se desprende de las narraciones de las fuentes clásicas: en las zonas costeras del Noreste, del Levante y en las inmediaciones de Cádiz. La única excepción a esta afirmación la encontramos en los continuos enfrentamientos entre romanos y cartagineses por el control del distrito minero de Sierra Morena que, hasta la fecha, solo están representadas por los contextos de Giribaile (Gutiérrez Soler et al. e.p.) y el campo de batalla de Baecula. (Figs. 6, 7 y 8).

Podemos apreciar cómo, de manera general, la arqueología del período bárquida en Iberia es una arqueología de niveles de destrucción, ya que la mayoría de los contextos disponibles del último tercio del siglo III a.C. derivan de estratos de incendio, destrucción o abandono repentino. Esta característica definitoria de la época bárquida en la península ibérica nos ayuda a 


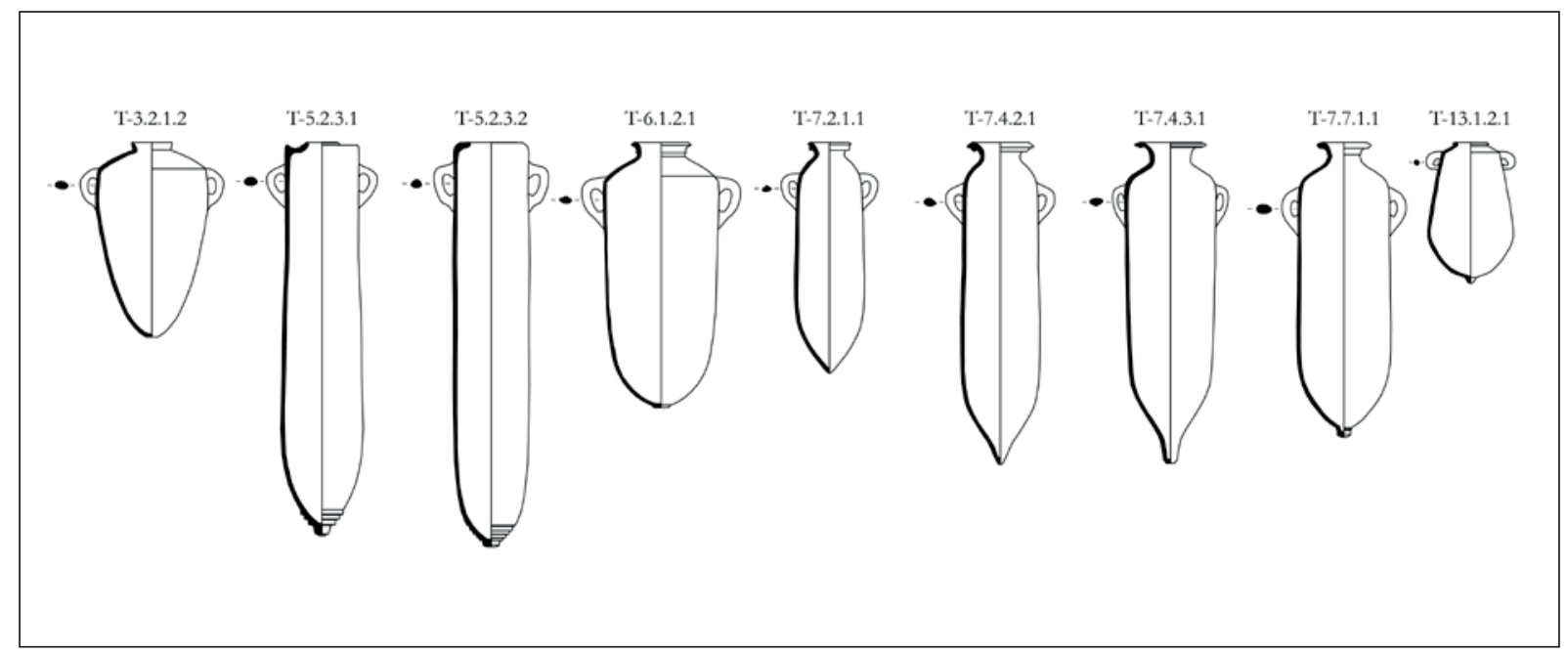

Figura 5. Tabla tipológica de ánforas cartaginesas distribuidas a finales del siglo III a.C.

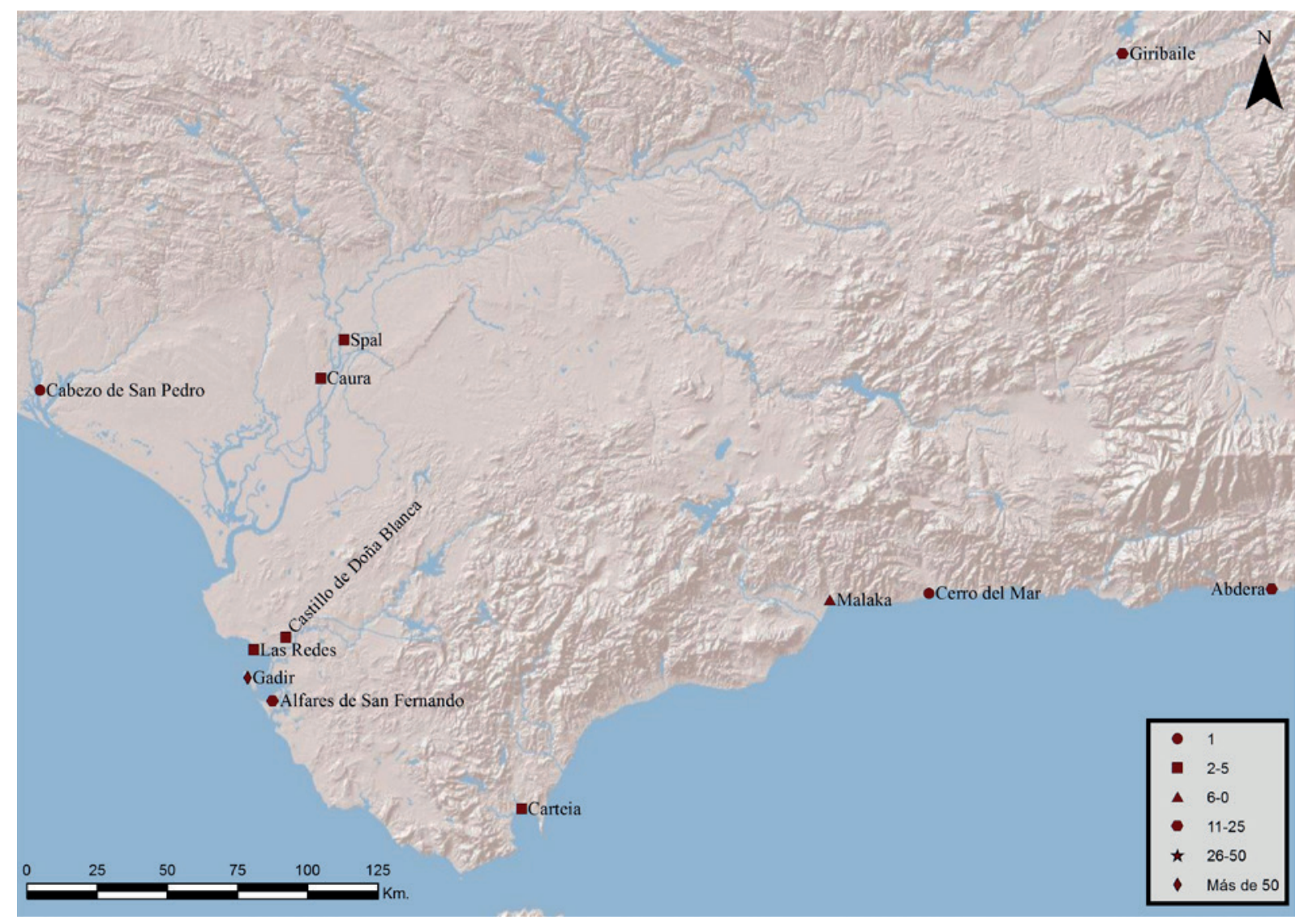

Figura 6. Mapa con la distribución de ánforas cartaginesas en el sur de la península ibérica. 


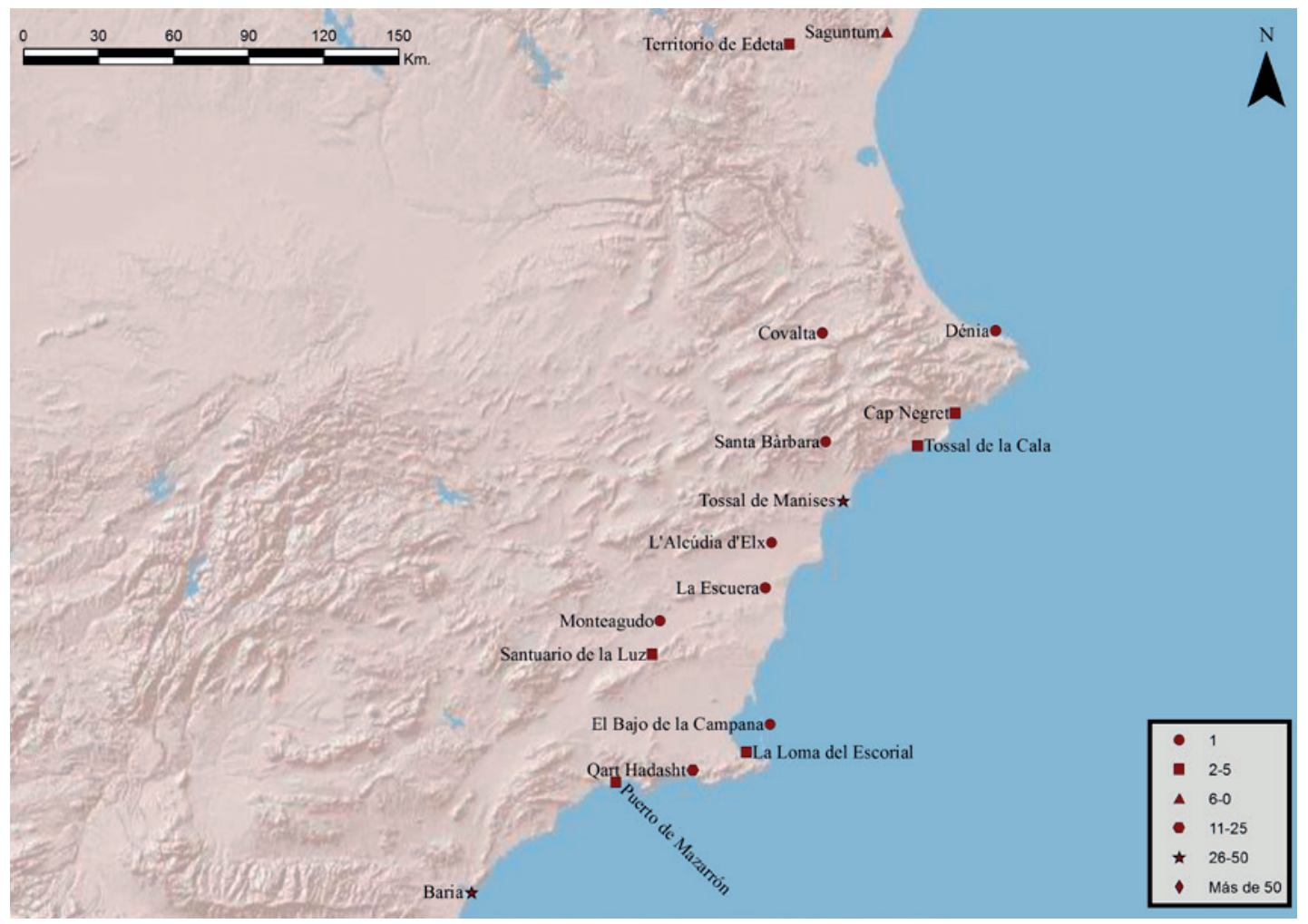

Figura 7. Mapa con la distribución de ánforas cartaginesas en el este de la península ibérica.

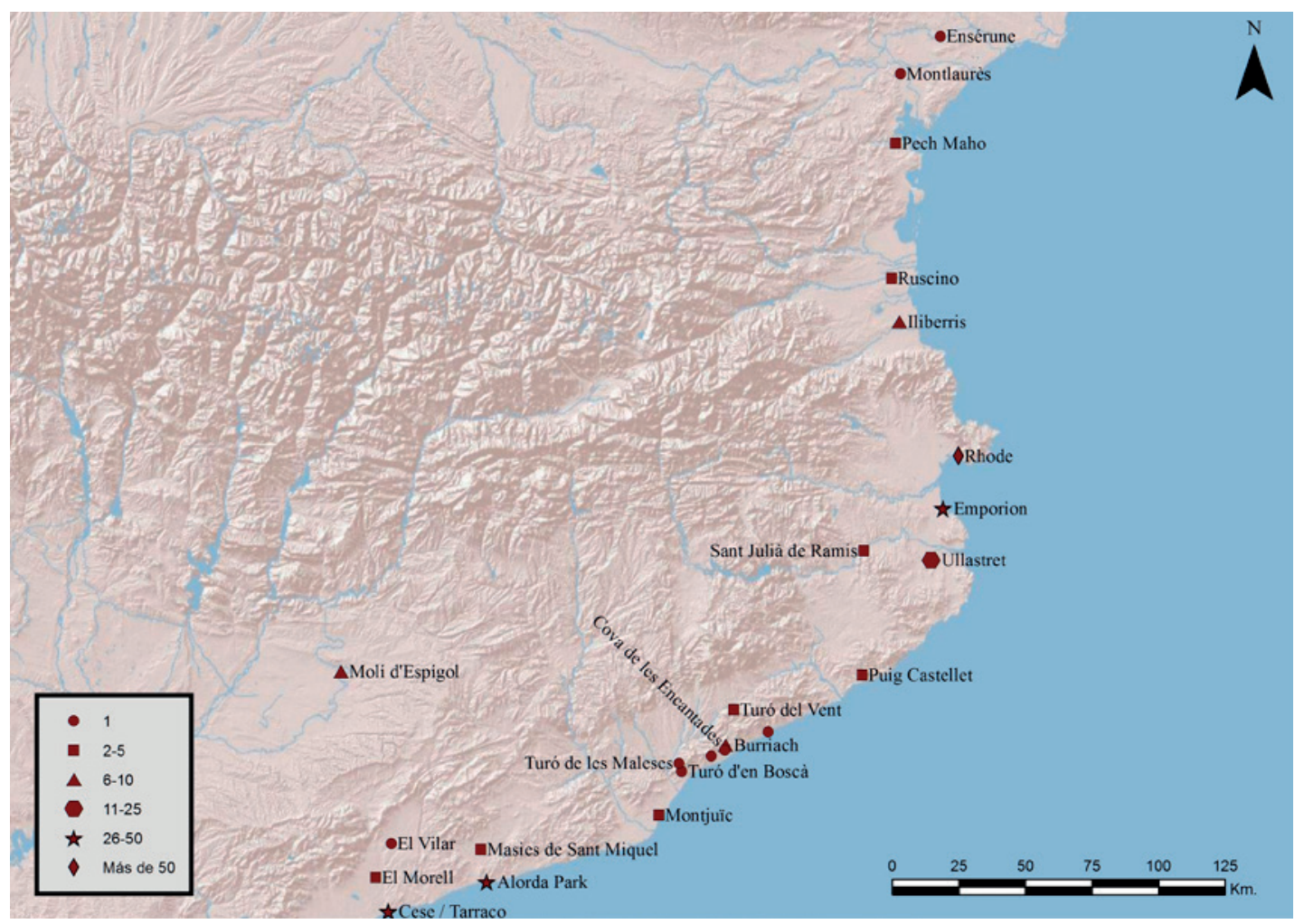

Figura 8. Mapa con la distribución de ánforas cartaginesas en el noreste de la península ibérica. 


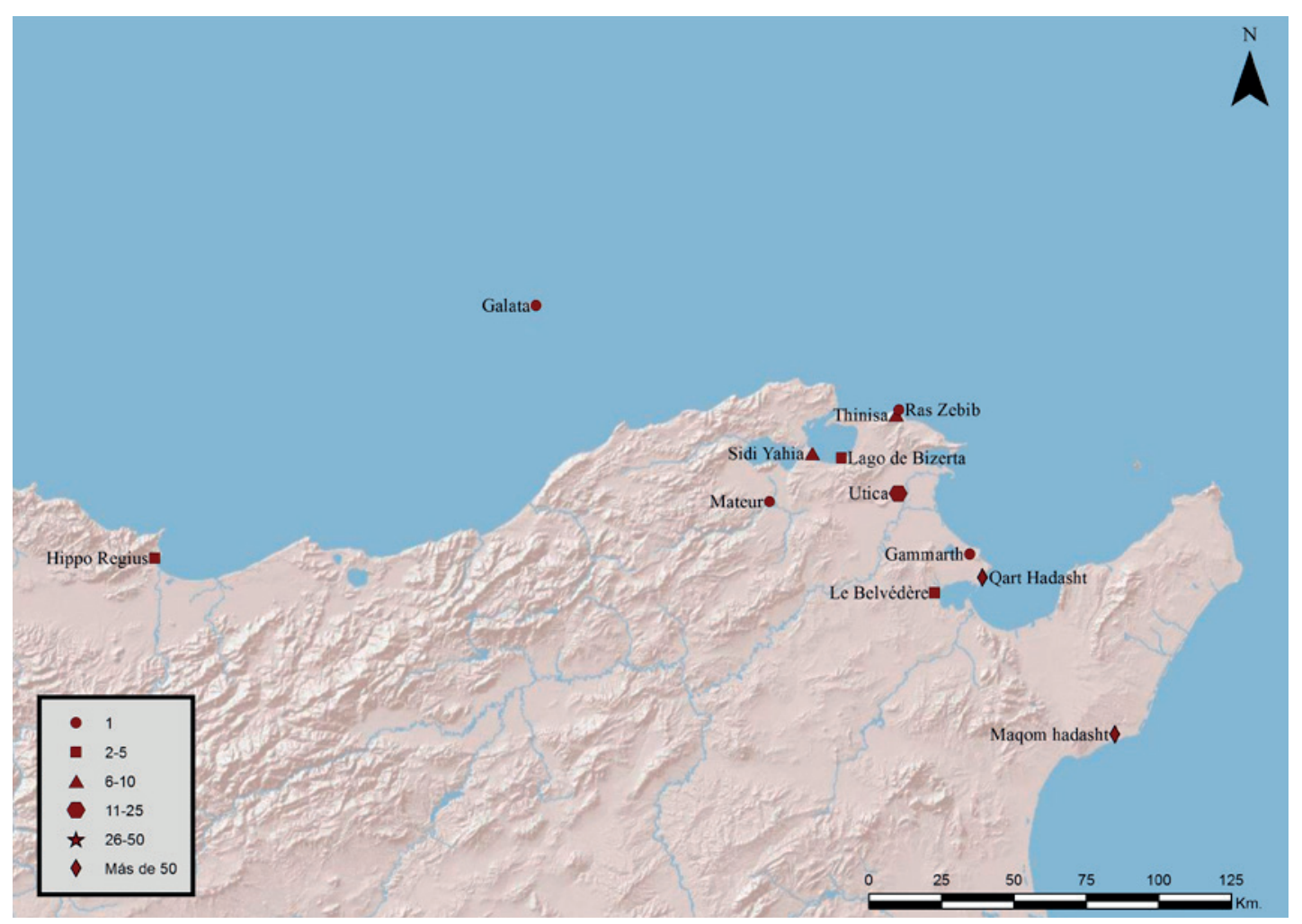

Figura 9. Mapa con la distribución de ánforas cartaginesas en Cartago y su hinterland.

justificar la gran cantidad de producciones cartaginesas documentadas y, a su vez, nos permite comprender mejor la gran entidad de la Segunda Guerra Romanocartaginesa en el frente ibérico, con decenas de miles de soldados enfrentados y decenas de asentamientos destruidos en las diferentes operaciones militares. A su vez, ofrece las condiciones ideales para poder estudiar detalladamente las características de las relaciones comerciales que se desarrollaban en aquel momento y el papel que cada uno de los implicados desempeñó, aspecto sobre el que incidiremos más adelante.

En cualquier caso, sí que es evidente, como hemos visto en el caso de los territorios ibéricos del Imperio Cartaginés, que el ejército se presenta en esta fase del último tercio del siglo III a.C. como el principal motor de la expansión comercial de Cartago. Así, los frentes de guerra, por pequeños que sean temporal o espacialmente, provocan una representación relativamente elevada de ánforas, como sucede en el caso del territorio norteafricano. Allí, a pesar de ser una de las zonas en las que la sistemática escasez de publicaciones conlleva, presumiblemente, una mayor desviación, se ha podido documentar hasta la fecha un sexto de toda la producción cartaginesa, convirtiéndose por lo tanto y de manera provisional en la segunda zona que más alimentos de la antigua colonia tiria consumía. Estos resultados, cuya proporción seguramente habrá que aumentar en un futuro, son perfectamente lógicos si tenemos en cuenta que en el territorio africano se encontraban los principales talleres alfareros de estas ánforas (Sáez Romero et al. 2004: 214-217; Maraoui Telmini y Bouhlel 2011) y, consecuentemente, los centros productores de los alimentos que se transportaban en ellas. Además, no hay que olvidar que la capital del Imperio Cartaginés seguía estando en la Qart Hadasht de Libia, una ciudad que a pesar de los intensos procesos coloniales del momento, debía estar densamente poblada $\mathrm{y}$, por lo tanto, sería consumidora preferente de estos alimentos. Asimismo, entre 204 y 201 a.C., la Segunda Guerra Romano-cartaginesa tuvo como frente prioritario el norte de África, donde Cartago movilizó a grandes ejércitos para intentar frenar el vertiginoso avance de las tropas romanas bajo el mando de $\mathrm{Pu}$ blio Cornelio Escipión (Pol. 14.1-10; 15.1-19; Liv. 29). Todo ello, junto con el comercio redistributivo dominante en la época, explica bien por qué tantas ánforas cartaginesas fueron documentadas en yacimientos del norte de África. (Figs. 9 y 10) 


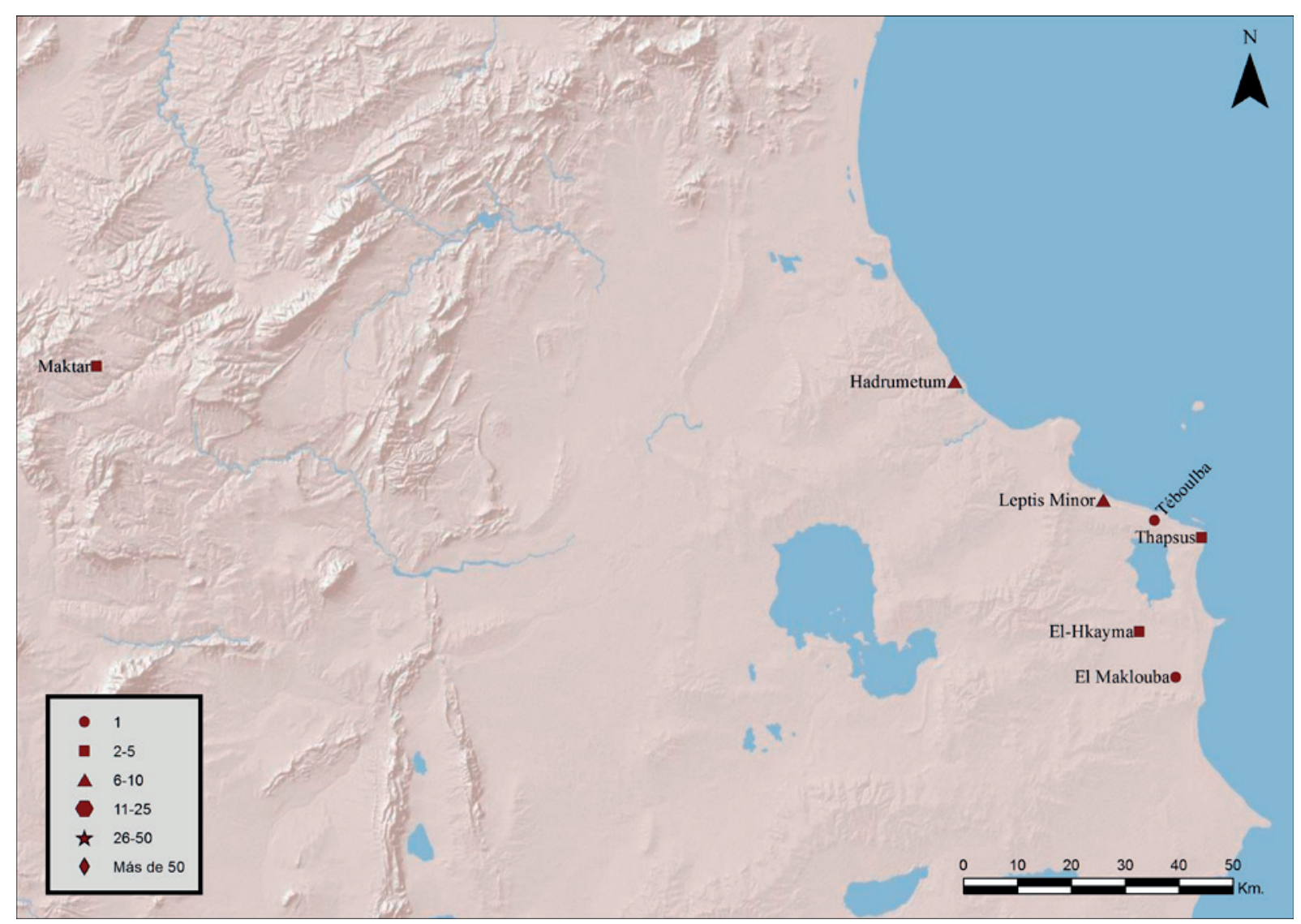

Figura 10. Mapa con la distribución de ánforas cartaginesas en los dominios territoriales de Cartago en el norte de África.

Con una representación de en torno al 10\% del total, encontramos por una parte al frente siciliano y por otra parte, al frente itálico. En el primer caso, el empeño cartaginés por recuperar la isla se materializó en continuados envíos de soldados y recursos (Pol. 7.4.8; 8.1.3 y 6; Liv. 21.50.3; 22.56.6-7; 24.6.2 у 6-8; 24.27.8; 24.35.17 ; 24.36.3; 25.23.3; 25.25.13; 25.27.2-3; у 25.40.5-6) durante los tres años que duró el conflicto en la zona (214-212 a.C.). Sin embargo, la concentración de los hallazgos de ánforas cartaginesas en la mitad occidental de Sicilia no cuadra con la narración de los autores clásicos mencionados, ya que las operaciones militares durante la Segunda Guerra Romano-cartaginesa se desarrollaron en la mitad oriental de la isla, especialmente en torno a las ciudades de Siracusa y Agrigento. Desafortunadamente, los hallazgos en esta zona se limitan a un único ejemplar de ánfora T-5.2.3.1 documentado en las excavaciones de Siracusa. Por ello, en esta ocasión, la presencia de productos cartagineses no se justifica con la necesidad de abastecer a sus ejércitos, sino que responde a la continuidad de un comercio de carácter regional que se había desarrollado entre el norte de África y la Sicilia occidental desde la colonización fenicia. En este caso, el aspecto más interesante es que la alta representación de ánforas cartaginesas en el extremo occidental de la isla es una prueba de que el comercio entre las ciudades fenicias de Sicilia, que estaban bajo dominio romano, y Cartago se mantuvo y creció a finales del siglo III a.C. lo que, a su vez, demuestra que los supuestos bloqueos comerciales derivados de las distintas afiliaciones en la guerra no fueron una realidad económica en aquél momento. (Fig. 11).

Por su parte, el frente itálico aparece aparentemente poco representado ya que cuenta con poco menos del $10 \%$ del total de ánforas cartaginesas, si bien fue, junto con Iberia, uno de los principales frentes de guerra tanto en el número de efectivos como en la duración del conflicto. No obstante, tal hecho no es tan anómalo si tenemos en cuenta que la mayor parte del abastecimiento de las tropas se llevaría a cabo a través de la producción alimenticia de las numerosas ciudades aliadas al bando cartaginés, concretamente por medio 


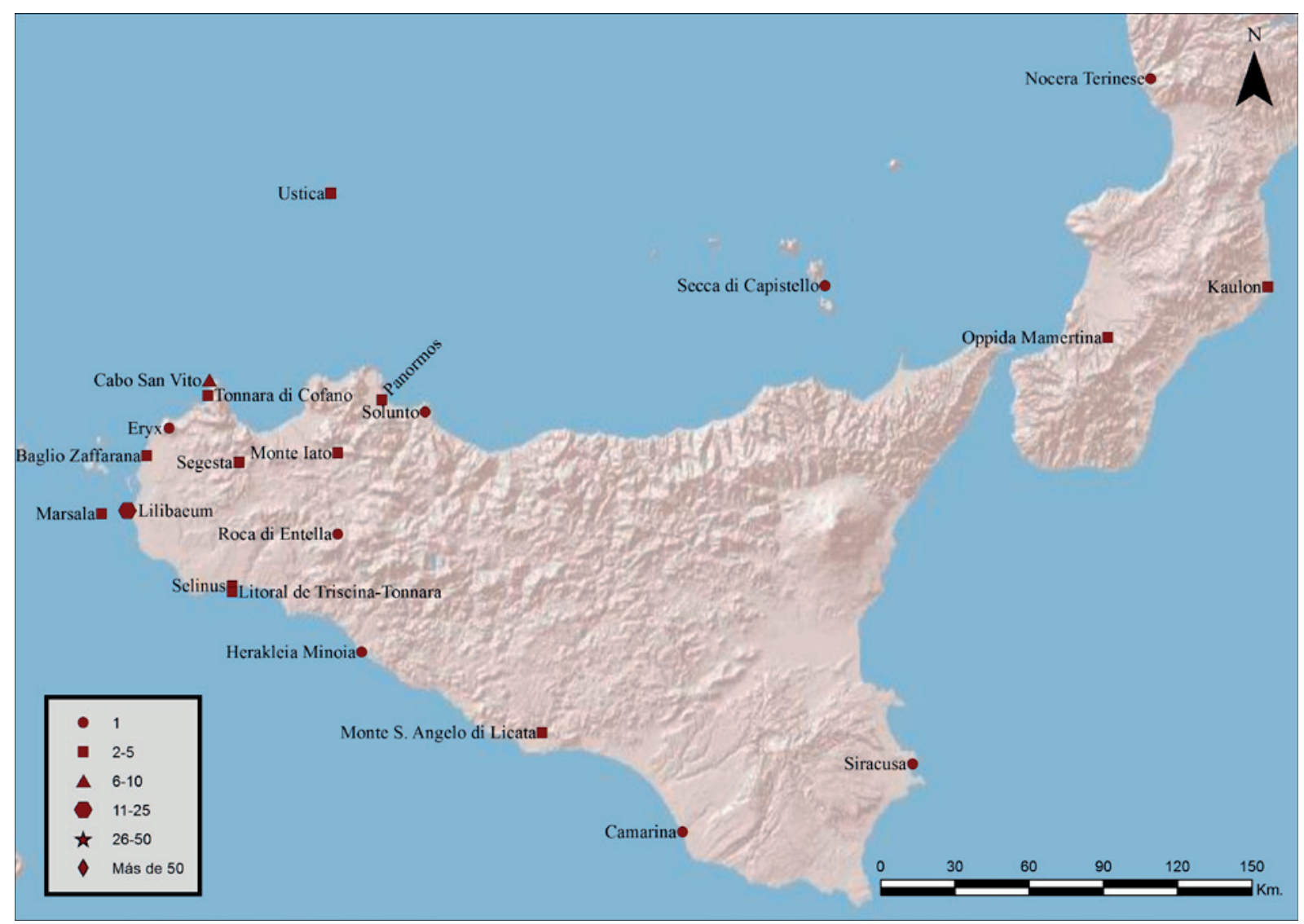

Figura 11. Mapa con la distribución de ánforas cartaginesas en la isla de Sicilia y el extremo sur de Italia.

de las ánforas denominadas magno-grecas y siciliotas por Vandermersch (1994). En cualquier caso, las ánforas procedentes de Cartago, a pesar de estar infrarrepresentadas en comparación con otras zonas, presentan una concentración en el tercio sur de Italia que cuadra con la vinculación de su distribución, al menos de un modo parcial, con el abastecimiento de tropas cartaginesas, ya que esa fue la zona donde la actividad militar fue más intensa y extensa.

Podríamos pensar incluso que las ánforas magnogrecas y siciliotas documentadas en Iberia no fueran solo el resultado de la continuación de las tradiciones comerciales con esa zona del Mediterráneo central de los decenios precedentes, sino también que respondieran al abastecimiento de vino a las tropas cartaginesas aprovechando el control de gran parte de la Magna Grecia por parte de Aníbal durante la mayor parte del conflicto bélico romano-cartaginés (Sala et al. 2004: 248). (Fig. 12).

Siguiendo esta lógica argumentativa, las siguientes zonas representadas corresponden a los frentes de guerra menores como las islas Baleares y Cerdeña. En el caso baleárico, por ejemplo, teniendo en cuenta el descrédito que ha merecido para la investigación la ya comentada noticia transmitida por Tito Livio (22.20.711) sobre el improbable ataque de Escipión a la ciudad y la isla de Iboshim, la única acción de carácter militar que podemos asociar con este archipiélago fue el reclutamiento forzoso que Magón Barca intentó efectuar tanto en Mallorca como en Menorca, teniendo éxito únicamente en la isla menor (Liv. 28.37.3-9; Zon. 9.10.10). De nuevo, el registro arqueológico no difiere demasiado de esta realidad ya que casi el $60 \%$ de las ánforas cartaginesas de este período documentadas en las islas Baleares aparecieron en yacimientos menorquines. (Figs. 13, 14 y 15).

La breve pero intensa revuelta sarda contra el dominio romano de la isla de Cerdeña encabezada por Hampíscora en el año 215 a.C. fue apoyada directamente por Cartago con sus recursos (Liv. 23.32.9-12; $23.34 .15-16 ; 23.40 ; 23.41 .1-8$ ). No debe sorprendernos, en este sentido, que un $5 \%$ de las producciones 


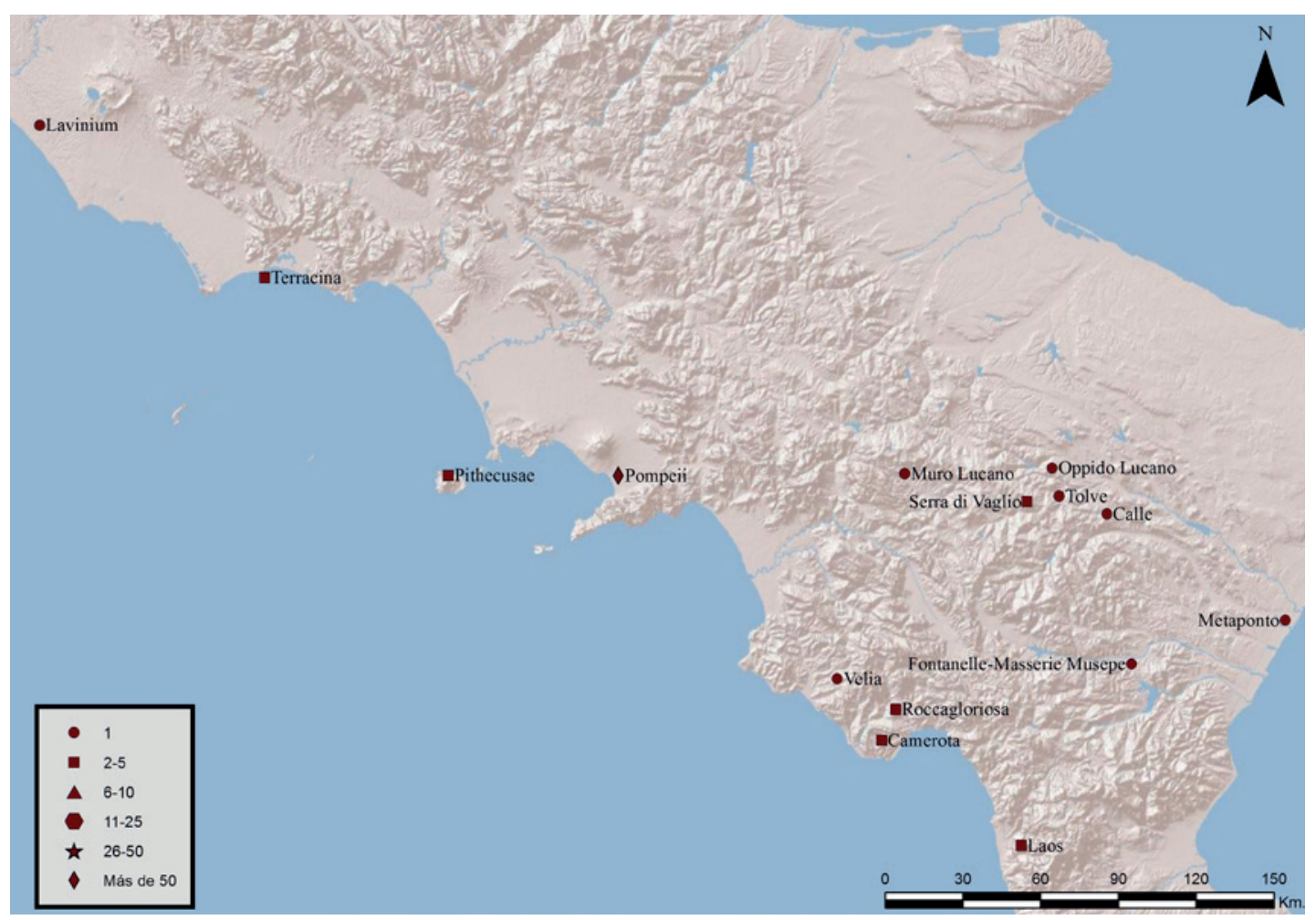

Figura 12. Mapa con la distribución de ánforas cartaginesas en Italia.

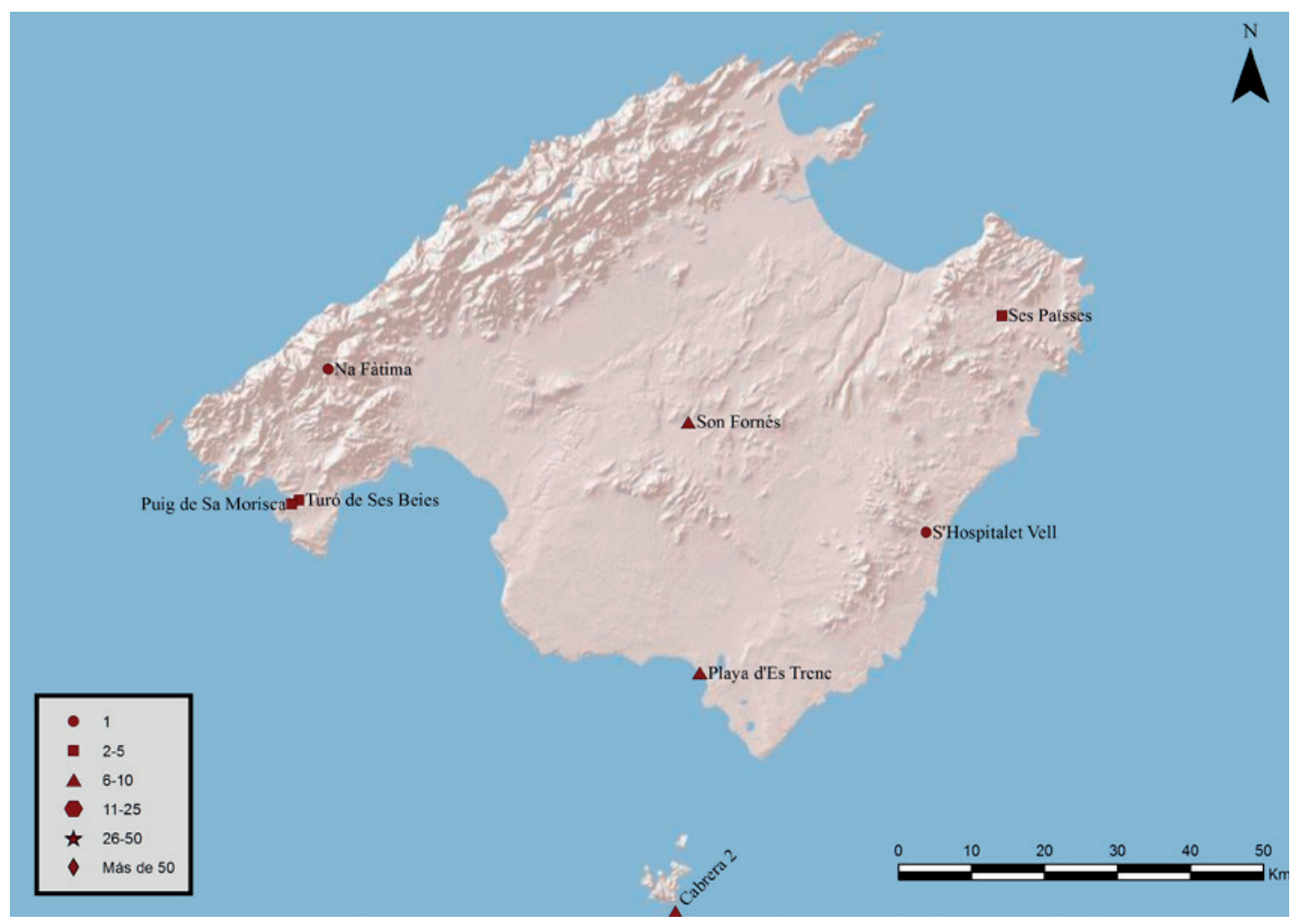

Figura 13. Mapa con la distribución de ánforas cartaginesas en la isla de Mallorca. 


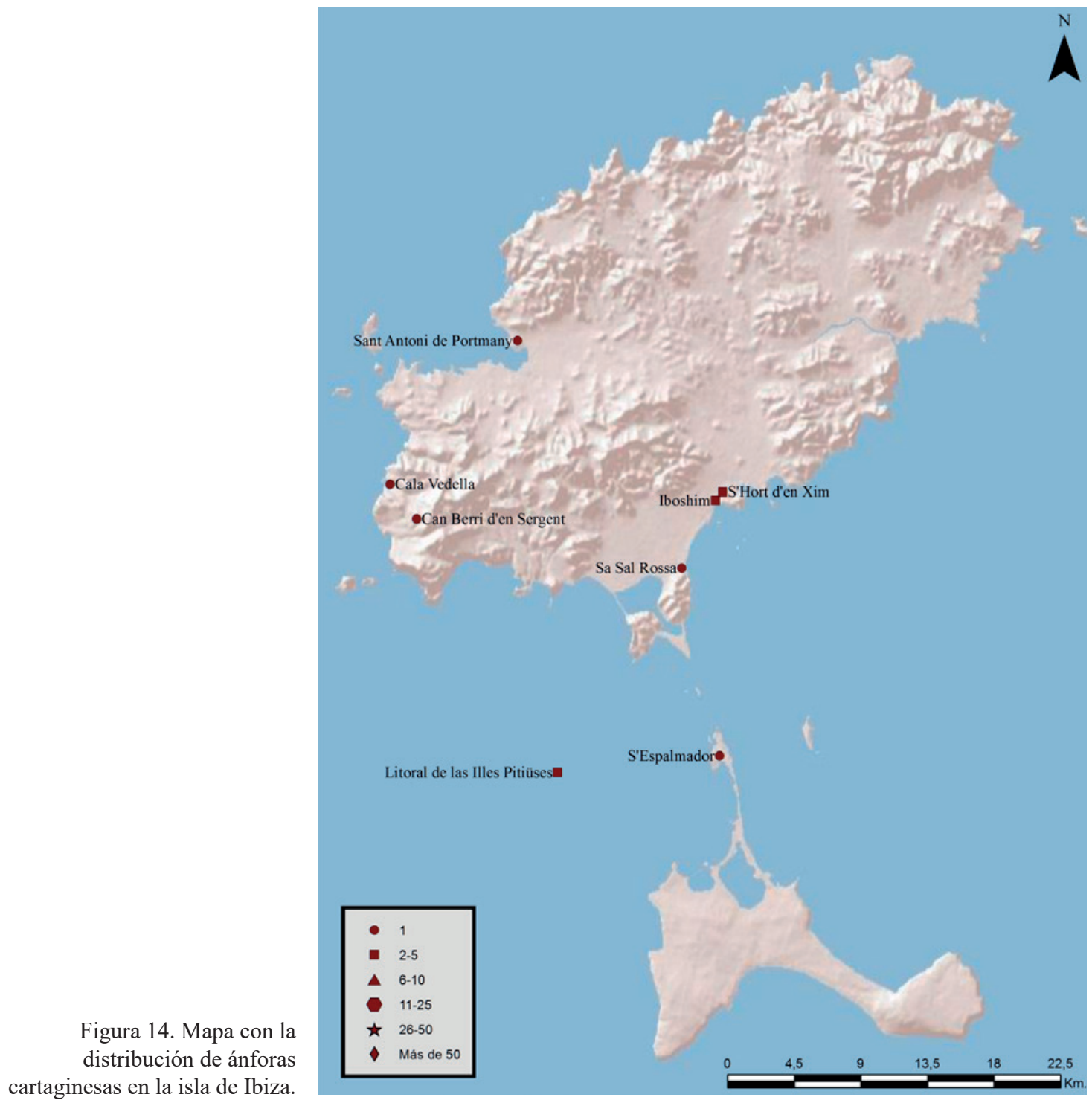

anfóricas cartaginesas se haya documentado en contextos sardos de finales del siglo III a.C. Además, al igual que la mayoría de los frentes bélicos, queda patente una innegable relación entre la dispersión de estos envases y la localización de los efectivos militares de la potencia norteafricana que se desprende de la lectura de las fuentes clásicas. Vemos, en este caso, cómo las importaciones de este tipo de ánforas se concentran en número y yacimientos cerca de Cornus (Cuglieri, Cerdeña), en la costa suroccidental, donde se concentraron los soldados cartagineses que apoyaron la rápidamente sofocada revuelta sarda. (Fig. 16).

Dejando de lado la relación directa que hemos evidenciado entre el comercio de Cartago y la necesidad de abastecer a sus soldados, no es nuestra intención menospreciar las relaciones de intercambio tradicionales entre la antigua colonia tiria y las distintas áreas y puertos del Mediterráneo central y occidental que, como veremos más adelante, continuaron siendo las formas predominantes de comercio marítimo a finales del siglo III a.C.

Por ello, completamos la difusión de los recipientes anfóricos cartagineses con la presencia relativamente baja de dichas importaciones en las zonas limítrofes con los dominios territoriales de Cartago, como el Maghreb, la Tripolitonia, la Galia y las islas de Malta y de Córcega. En estos lugares, así como la lejana Atenas, nos encontramos ante un comercio que guarda 


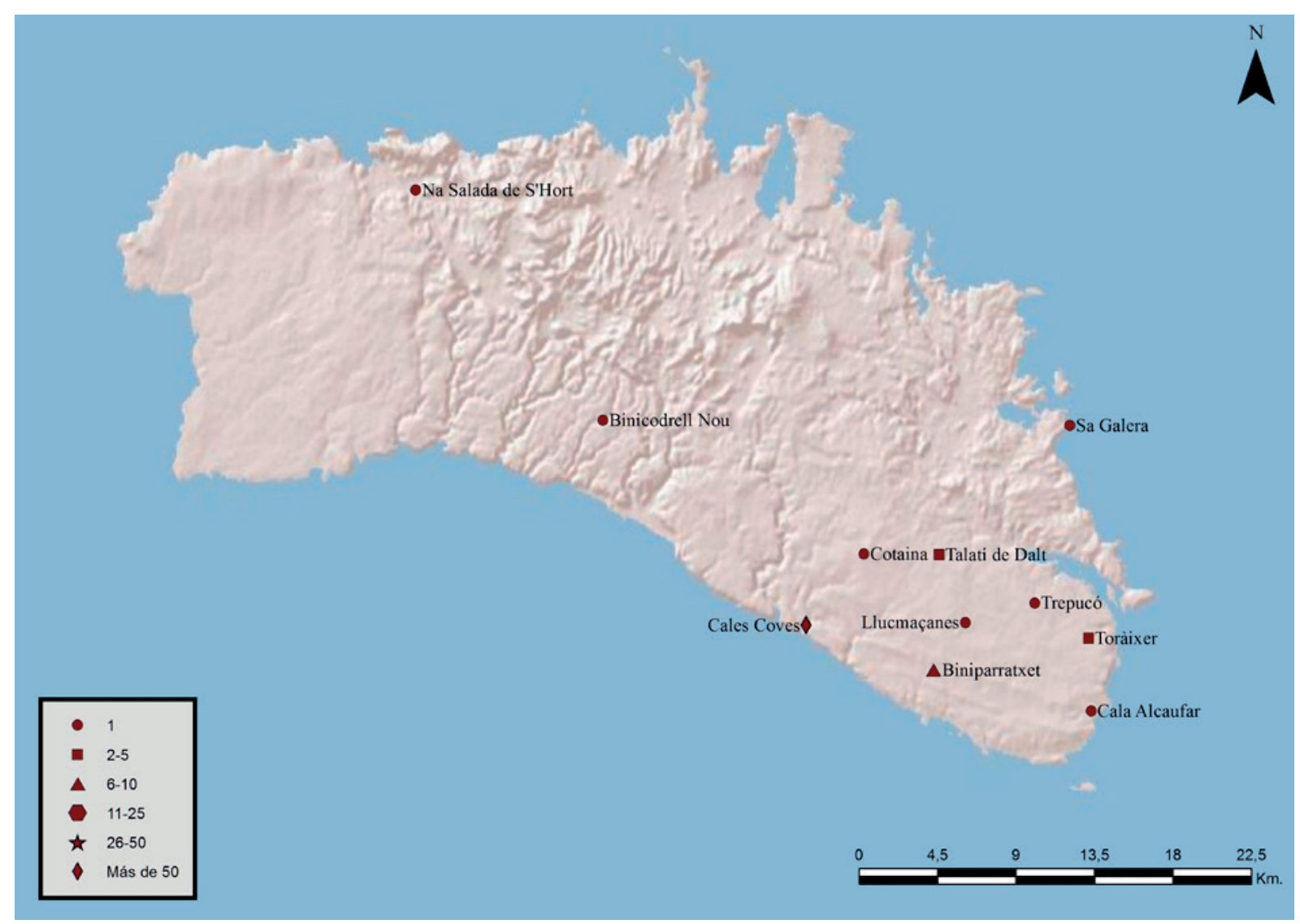

Figura 15. Mapa con la distribución de ánforas cartaginesas en la isla de Menorca.

escasa o nula relación con el movimiento de tropas, manteniendo en este sentido unos porcentajes de representación similares a las fases inmediatamente precedentes. (Figs. 17, 18, 19 y 20).

\section{LAS CARACTERÍSTICAS DEL COMERCIO CARTAGINÉS EN ÉPOCA BÁRQUIDA}

A continuación, sin abandonar esta visión general del comercio cartaginés en el Mediterráneo, podemos observar cómo, a grandes rasgos, las características que lo definían en las fases precedentes se mantienen, por norma general, inalteradas. En primer lugar, las relaciones comerciales cartaginesas de finales del siglo III a.C. son propias de un intercambio predominantemente marítimo y fluvial y, por lo tanto, basado en un comercio directo con los principales puertos del Mediterráneo que, posteriormente, llevan a cabo una labor redistributiva de los productos cartagineses en los asentamientos del entorno. Este rasgo, definitorio de la mayor parte de las relaciones de intercambio de este período en el Mediterráneo, explica la concentración de ánforas cerca de la costa y de los citados puertos comerciales.

Aunque Cartago se adhiere de manera general a esta tendencia, la necesidad de abastecer a soldados y colonos en sus dominios territoriales, el ya comentado refuerzo de las vías comunicación terrestre y las especiales características conservantes del recipiente anfórico (Carretero 2007: 4), provocaron una ampliación de la presencia de ánforas cartaginesas hacia el interior, llegando a los casos extremos del santuario númida de Maktar (Siliana, Túnez) y la ya mencionada fortificación, posiblemente cartaginesa, de Giribaile, a más de 150 y $250 \mathrm{~km}$ respectivamente de distancia en línea recta de la costa. (Fig. 21).

La segunda característica que define el comercio cartaginés de finales del siglo III a.C. es la gran variabilidad de sus ánforas, con 18 tipos completamente diferenciados distribuidos en 5 grupos formales distintos. Paradójicamente, este hecho va en contra de las 


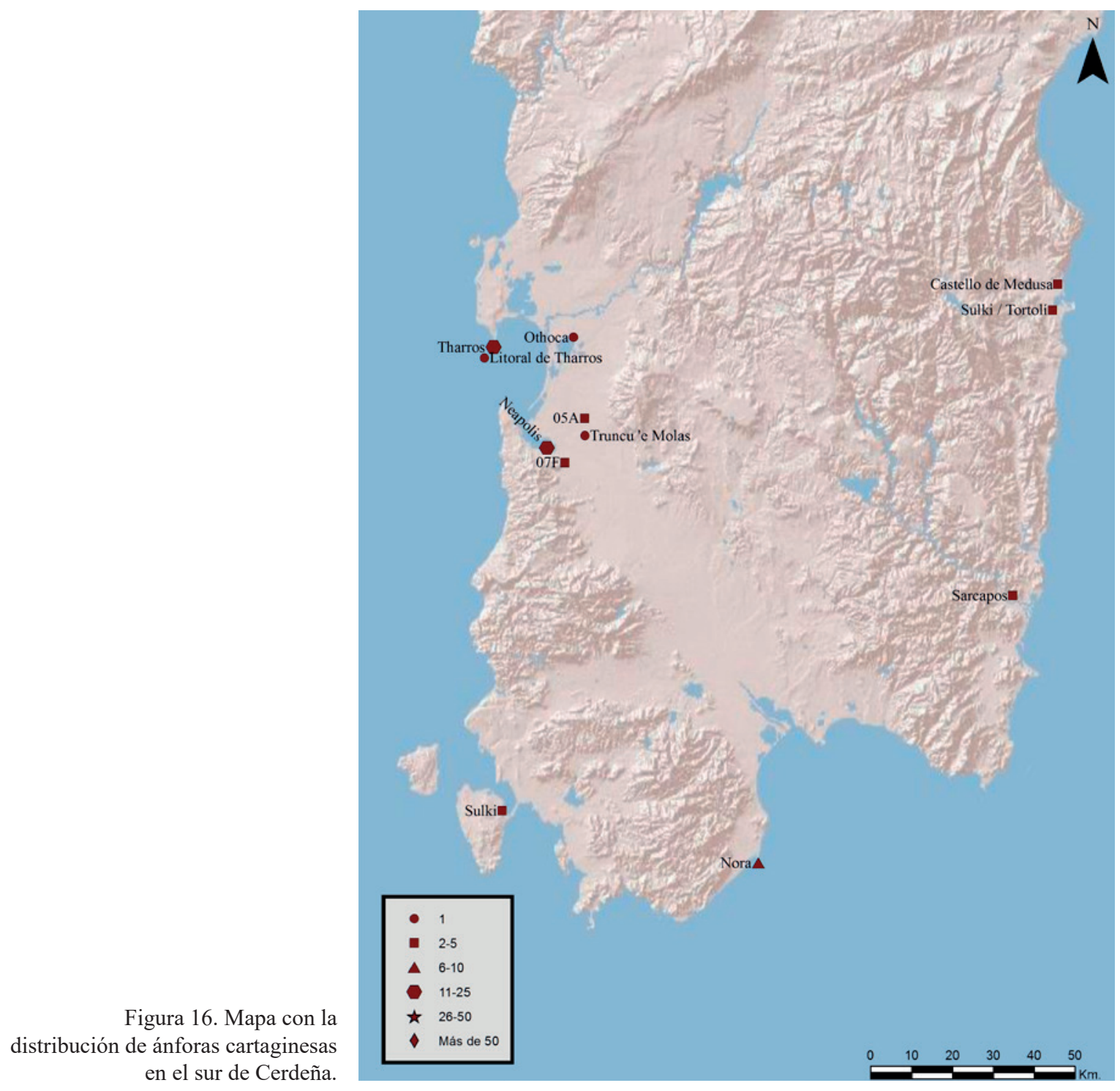

tendencias productivas de la mayor parte de los alfares del Mediterráneo central y, en menor medida, occidental donde la producción se encaminaba hacia una estandarización y simplificación de cada uno de sus repertorios. Creemos que esta gran variedad no debe vincularse de manera exclusiva a la, por el momento, poco reveladora cuestión de los contenidos. En realidad, este amplio repertorio anfórico respondería, según nuestra interpretación, a la existencia de una gran competitividad entre las principales familias dirigentes cartaginesas por el control de la producción y la exportación de sus productos alimenticios y, a través de ella, de los beneficios económicos que conllevaría para estas familias el abastecer el ingente número de efectivos militares movilizados.
Una última característica que define el comercio cartaginés del último tercio del siglo III a.C. es la forma en que las ánforas fueron transportadas del centro productor a los centros receptores. De nuevo, se trata de una característica común para el resto de comunidades que intervinieron en las relaciones de intercambio marítimas en el Mediterráneo central y occidental. Nos referimos a la heterogeneidad de la carga de los navíos de este período, hecho que debemos relacionar con el predominio del comercio redistributivo al que ya hemos aludido. En efecto, la mayoría de los pecios de este período presenta una carga variada en cuanto a su origen (Hopper 1979: 48), es decir, con producciones de procedencias diversas que, además, no tienen 


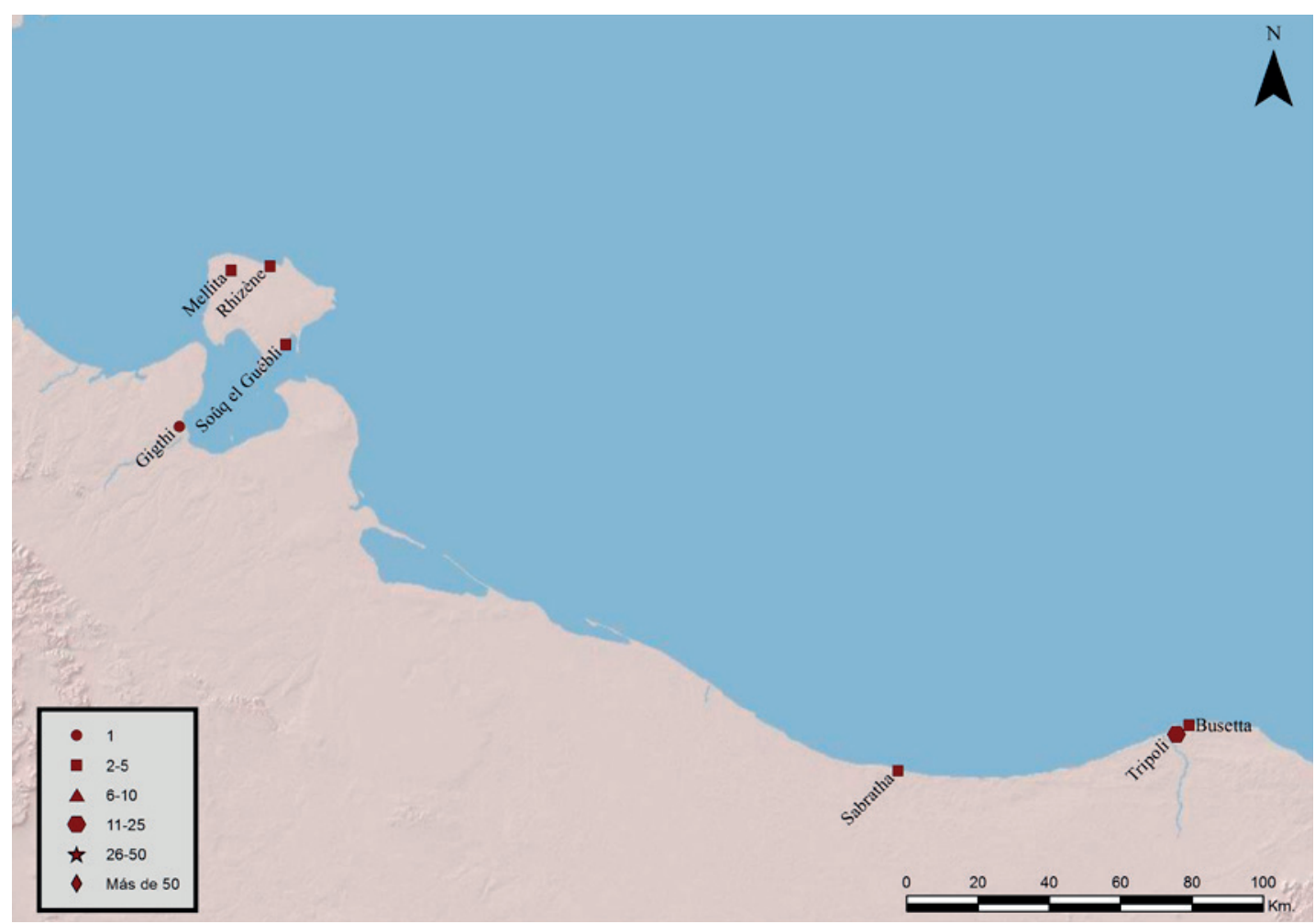

Figura 17. Mapa con la distribución de ánforas cartaginesas en la Tripolitania y la isla de Djerba.

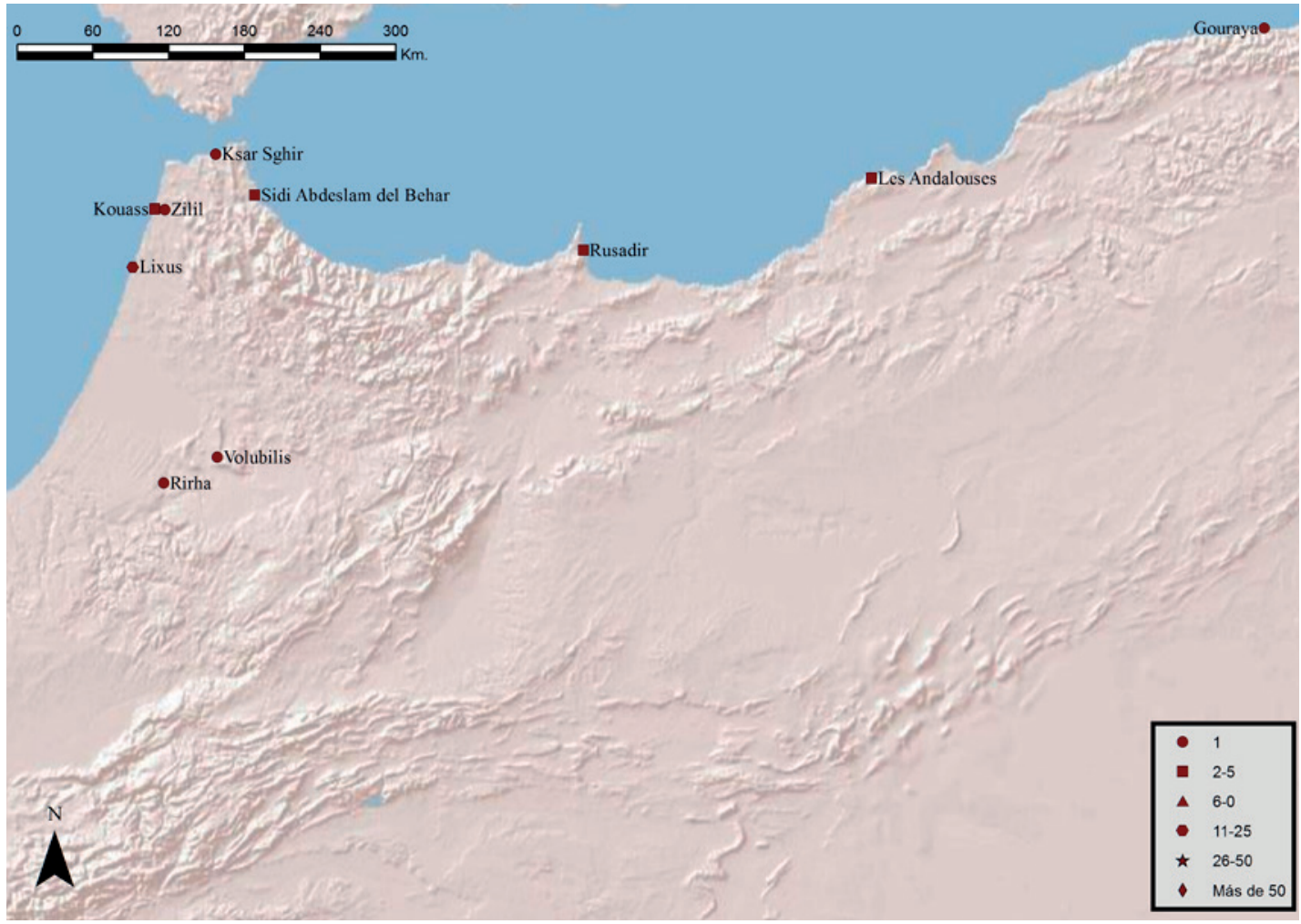

Figura 18. Mapa con la distribución de ánforas cartaginesas en el Magreb. 


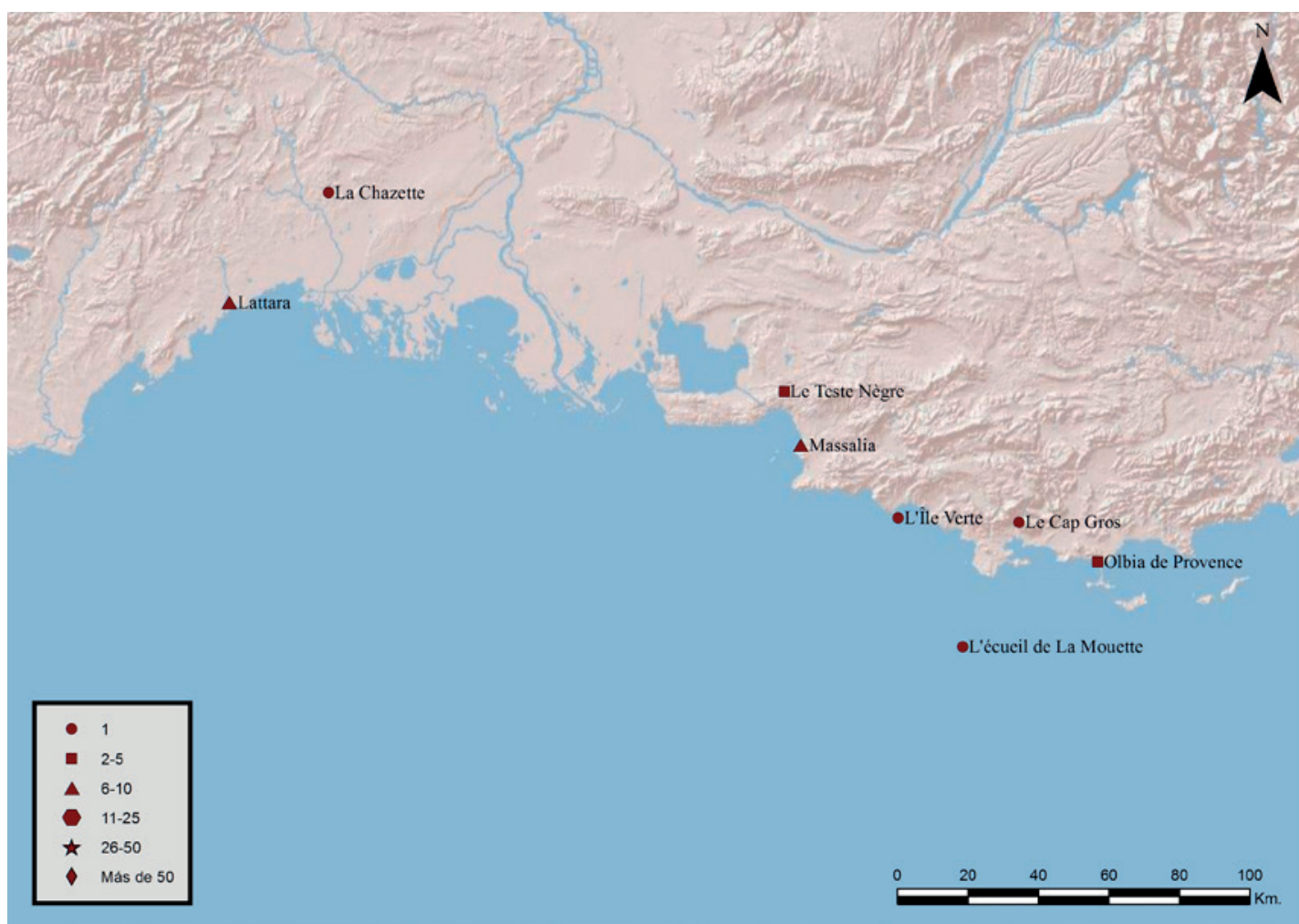

Figura 19. Mapa con la distribución de ánforas cartaginesas en la Galia.

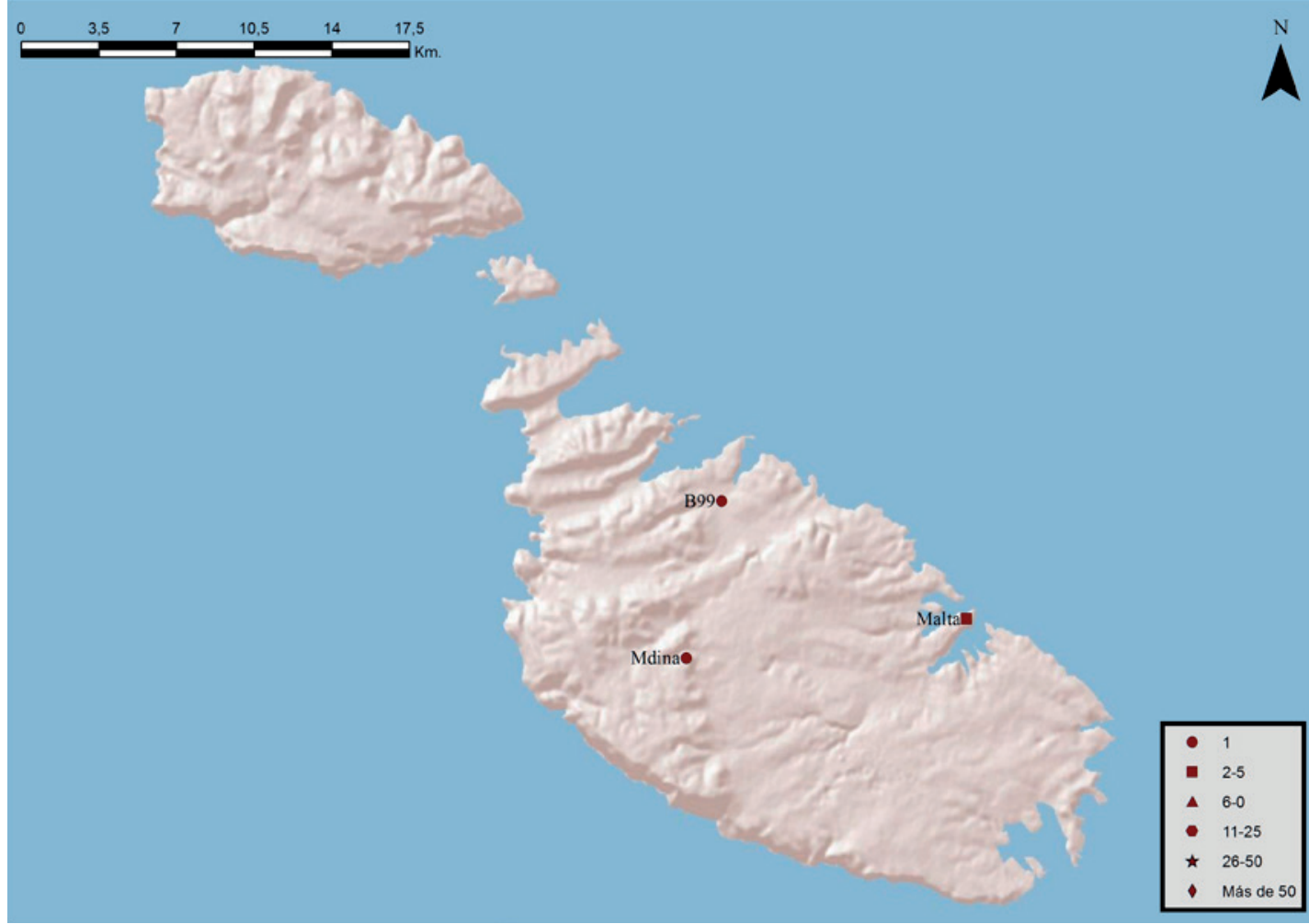

Figura 20. Mapa con la distribución de ánforas cartaginesas en la isla de Malta. 


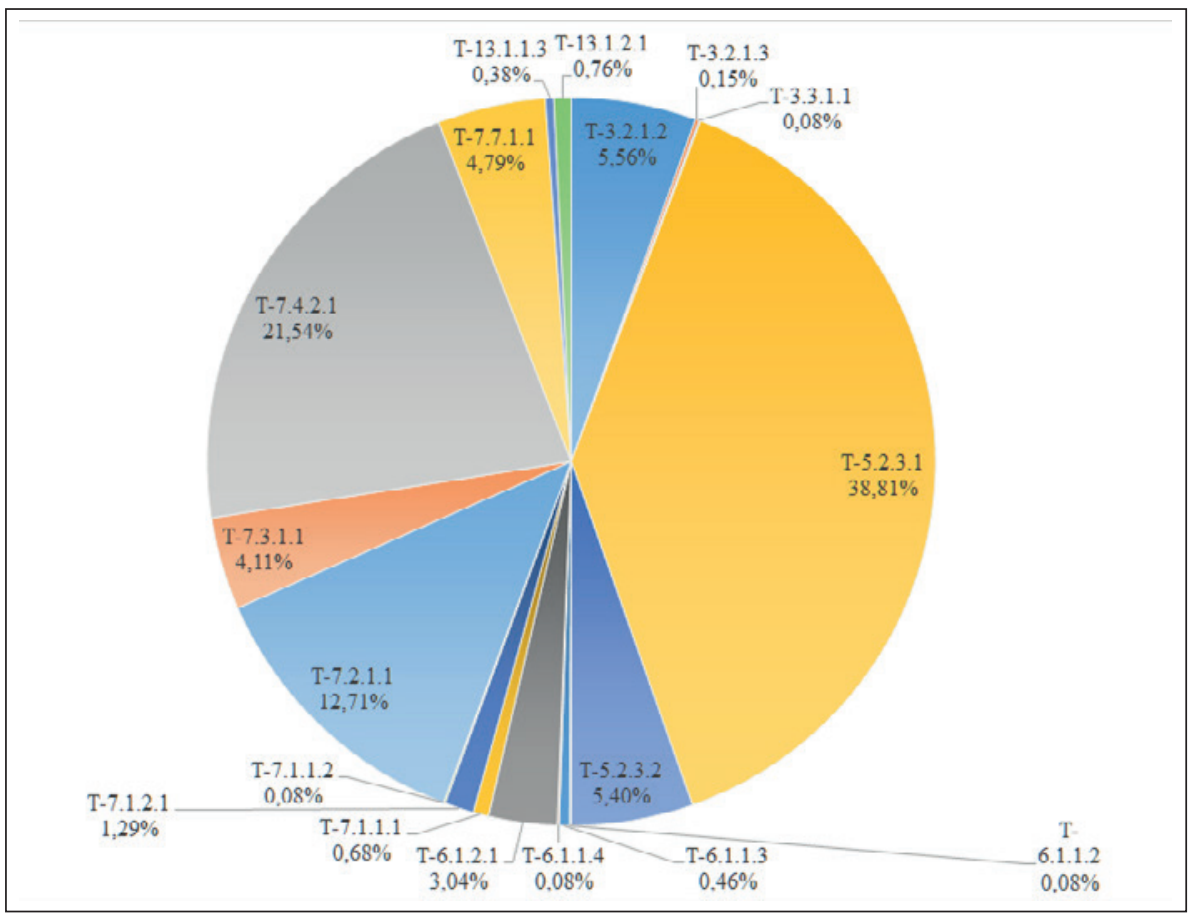

Figura 21. Gráfico con la relación de los diferentes tipos anfóricos cartagineses documentados en el Mediterráneo y la costa atlántica. por qué pertenecer al mismo ámbito productivo del que es oriunda la tripulación. En este sentido, por ejemplo, contamos con la evidencia del pecio de Cabrera 2 (Mallorca, Islas Baleares) (Cerdà 1974: 437-445; 1978: 89105; Parker 1992: 80-81) cuyo cargamento principal estaba conformado por las ánforas cartaginesas propias de finales del siglo III a.C. (Guerrero et al. 1991: 26) y su contrapartida ebusitana.

Otro ejemplo de la diversidad en la carga de los barcos comerciales del siglo III a.C. que operaban en la parte occidental del Mar Mediterráneo lo encontramos en el pecio documentado en la Cala Binisafuller (Menorca, Islas Baleares), navío de origen probablemente ebusitano que se hundió como resultado de un incendio entre el primer tercio del siglo III (Guerrero et al. 1989: 115-125; 1991: 10 y 22-24) y principios del siglo II a.C. (Parker 1992: 73-74). La carga principal consistía en ánforas ibéricas pero también se documentaron varias producciones de origen ebusitano y al menos una centro-mediterránea.

Los numerosos pecios localizados cerca de la pequeña isla de Pantelleria, situada al sur de Sicilia, también presentan esta característica ya que la carga de los barcos hundidos en Cala Gadir 1, Cala Tramóntana 1, 2 y 3 estaba compuesta tanto por amplios y variados conjuntos de ánforas cartaginesas de finales del siglo III a.C. como por recipientes magno-grecos y siciliotas de ese período (Abelli 2011: 62-63, 66 y 68). (Fig. 22).
Sucede lo mismo con el navío mercante probablemente de origen cartaginés que pretendía alcanzar Massalia cuando las inclemencias del tiempo provocaron su naufragio cerca de la costa meridional de Córcega. Aunque la carga principal del pecio la constituían bloques de vidrio azul, el espacio de la bodega también estaba ocupado por ánforas griegas orientales, magnogrecas y siciliotas y cartaginesas, alcanzado estas últimas una representación aproximada del 12\% del total del conjunto anfórico documentado (Cibecchini et al. 2012: 34, 36-38 y 63). (Fig. 23).

El mismo comportamiento respecto a la diversidad de la carga lo comprobamos también en los mercantes, presumiblemente helenos, que se hundieron a finales del siglo III a.C. en las inmediaciones de las costas de Massalia. Nos referimos, por un lado, al polémico pecio de Gran Congloué A (Benoit 1961: 28-32 y 36-41; Parker 1992: 200-201), cuya carga estaba compuesta principalmente de ánforas magno-grecas, pero donde también aparecieron envases rodios y recipientes de Quíos y Cnidos. Por otra parte, en el pecio de Pointe Lequin B (Parker 1992: 323), junto a la carga principal compuesta de nuevo por ánforas magno-grecas, se documentaron recipientes comerciales fenicios occidentales.

El único pecio de finales del siglo III a.C. en el Mediterráneo occidental que podría no adherirse a esta tendencia 


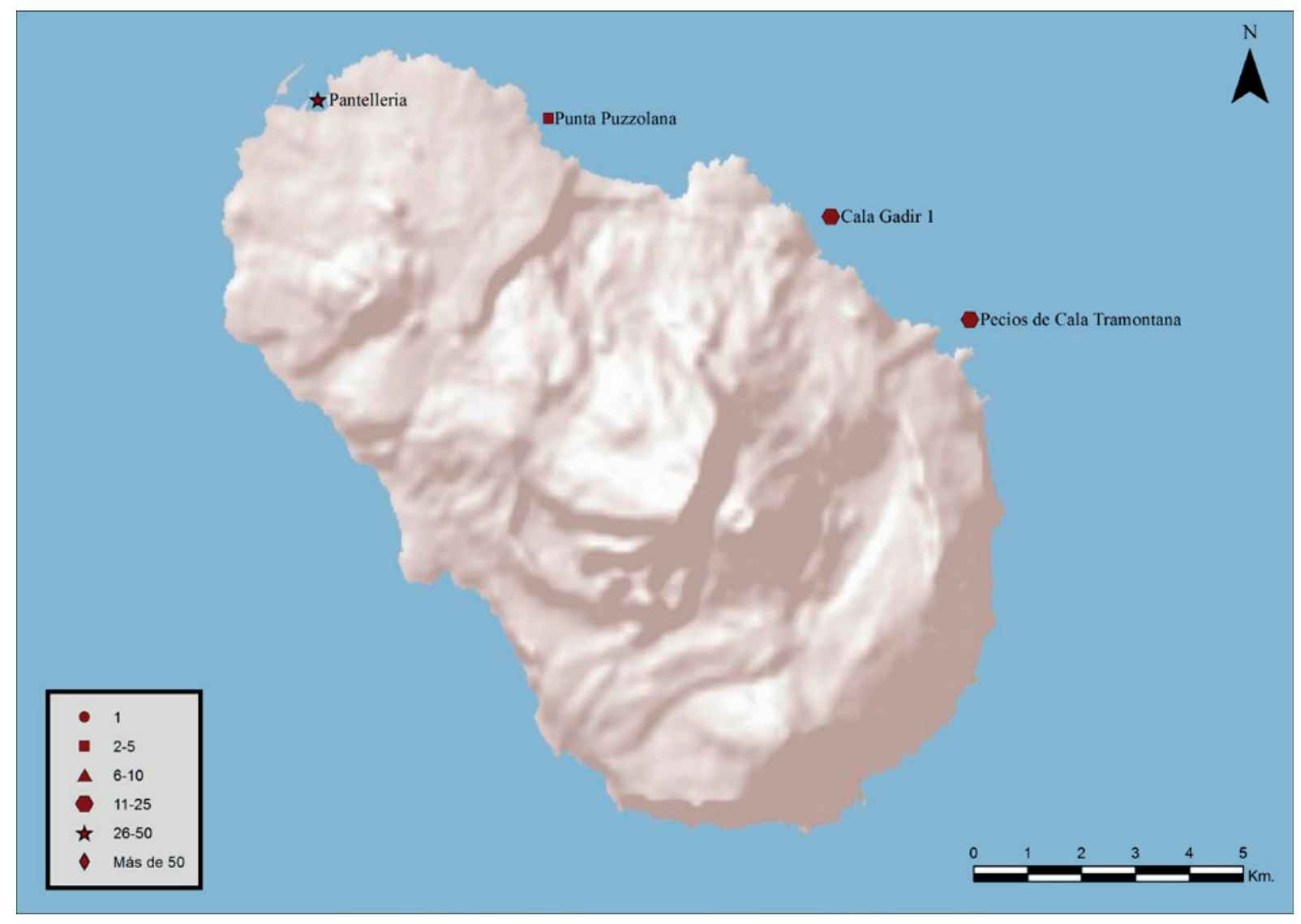

Figura 22. Mapa con la distribución de ánforas cartaginesas en la isla de Pantelleria.

es el de Bon Capó, hundido cerca de L'Ametlla de Mar (Tarragona). Para Asensio y Martín i Menéndez (1999: 142-144) se trataría de un mercante itálico anegado en el último cuarto del siglo III a.C. de cuyo cargamento solo se han podido recuperar ánforas magno-grecas. Tal homogeneidad en la carga, sin embargo, quizás habría que vincularla con el expolio al que el pecio ha sido sometido por los submarinistas furtivos más que a una actitud divergente por parte de los comerciantes itálicos.

A pesar de que las ánforas producidas en Cartago están presentes de una manera categórica en extensas zonas del Mediterráneo central y occidental, especialmente en Iberia, el incipiente comercio imperialista cartaginés solo representaba una pequeña parte del total de las relaciones que se desarrollaban entre las distintas comunidades que habitaban las costas y, en menor medida, el interior de esta área. Por comercio imperialista (Alonso-Núñez 1989: 8) entendemos el aprovechamiento de la estructura administrativa y las relaciones diplomáticas de Cartago para obtener un beneficio económico por parte de las principales familias dirigentes de la política cartaginesa que, en el contexto que nos ocupa, implicaba el abastecimiento de parte de los suministros que necesitaban los numerosos soldados del ejército al servicio de Cartago. En el registro arqueológico, la concentración de estos recipientes en niveles de destrucción asociados a la Segunda Guerra Romano-cartaginesa y en los enclaves en los que sabemos o intuimos que se establecieron guarniciones de soldados o colonias de veteranos es el reflejo de este embrionario comercio imperialista cartaginés que, en fases posteriores, fue ampliado y mejorado por Roma, la potencia vencedora de la guerra por la hegemonía en el Mediterráneo.

Para demostrar la escasa incidencia de este tipo de intercambio en las relaciones mercantiles de finales del siglo III a.C. y, por lo tanto, en la economía de las distintas comunidades del Mediterráneo occidental, haremos un breve repaso al comercio exterior de los asentamientos mejor estudiados de Iberia. En primer lugar, contamos con nuestro pormenorizado estudio sobre el registro material del nivel de conquista romana de Baria (Almería) fechado c. 209 a.C. en el 


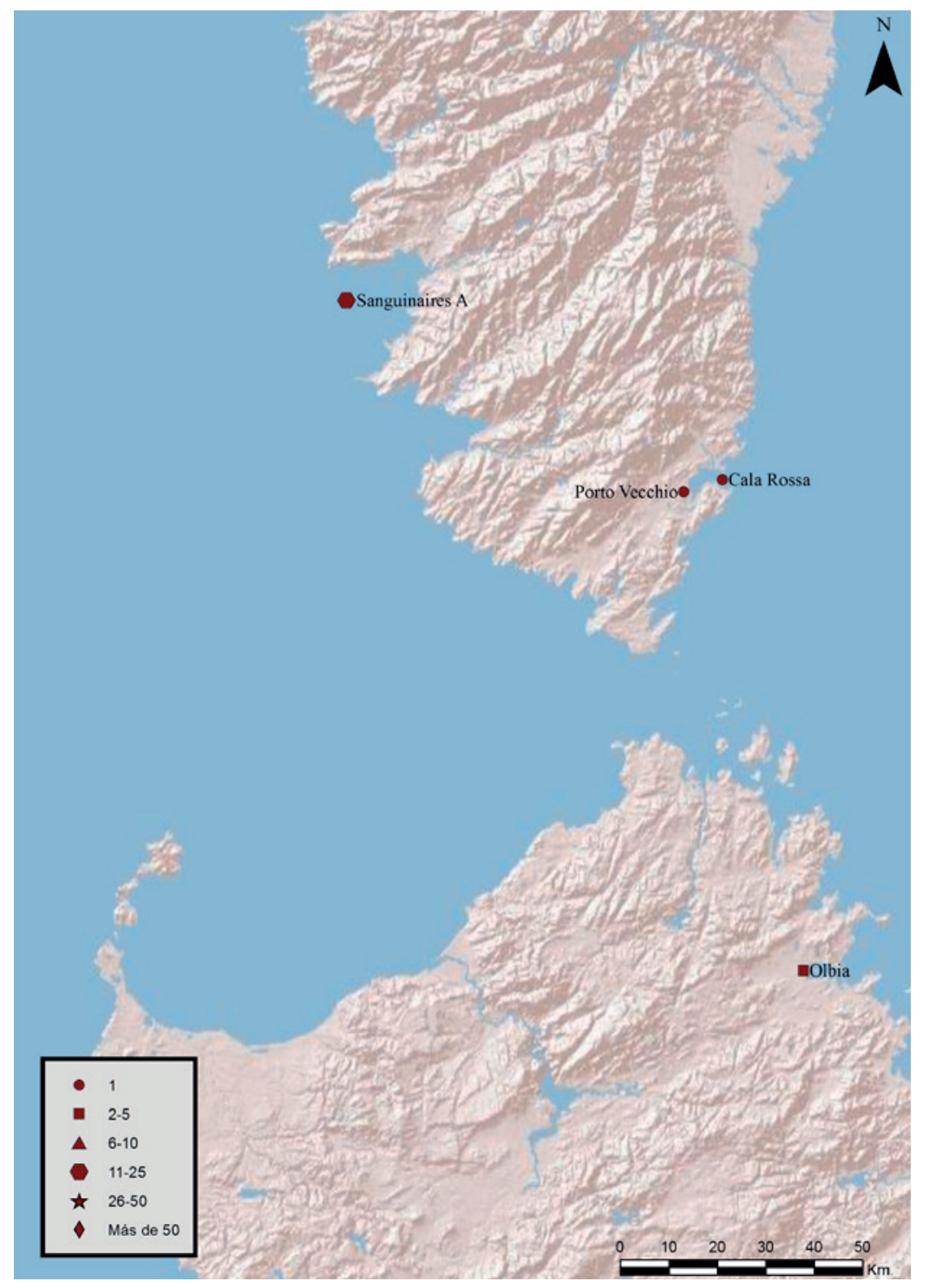

Figura 23. Mapa con la distribución de ánforas cartaginesas en el norte de la isla de Cerdeña y en el sur de la isla de Córcega.

que las importaciones cartaginesas suponen únicamente el 18\% del total de ánforas alóctonas, aunque superando los porcentajes de las producciones gaditanas y ebusitanas (Martínez Hahnmüller 2012: 132-136). Esta elevada representación respondería, sobre todo, a la cercanía de la ciudad fenicia occidental con respecto a Qart Hadasht, capital de los dominios cartagineses en la península ibérica, y el importante papel de la primera como puerta de acceso a los centros ibéricos de la Bastetania.

Los resultados que nos proporciona Baria casan a la perfección con otros estudios de materiales similares al nuestro, procedentes de otros asentamientos con niveles de finales del siglo III a.C. de Iberia. En este sentido, por ejemplo, en la Palaia Polis de Emporion (Aquilué et al. 2004: 171, 173 y 178), aunque el material anfórico es relativamente escaso y no es excesivamente representativo estadísticamente, sí que nos permite estimar la tendencia comercial del momento en el que las llamadas producciones púnicas, concretamente ánforas de origen ebusitano, cartaginés y turdetano, compiten casi en igualdad con las importaciones magno-grecas.

Un panorama similar lo encontramos en la zona de Saguntum (Valencia) (Bonet et al. 2004: 206-207). Allí, las ánforas del mundo fenicio y cartaginés son predominantes entre las importaciones documentadas, alcanzando el 48,6\%, aunque el último lugar dentro de las mismas lo ocupan las ánforas de origen norteafricano. 
En los asentamientos estudiados de la Contestania esta tendencia se mantiene. Así, en el nivel de destrucción de La Escuera (Alicante), de finales del siglo III a.C., aunque el material anfórico fenicio-cartaginés implica 4/5 partes de los elementos importados, Cartago es la que muestra unos porcentajes más bajos con solo dos ánforas documentadas (Sala et al. 2004: 239).

A diferencia de los casos anteriores, donde la presencia de productos cartagineses es constante pero relativamente baja, la vinculación directa del Tossal de Manises (Alicante) con el programa bárquida queda perfectamente patente, ya que aquí los productos cartagineses están ampliamente representados alcanzando un 32,5\% de las importaciones (Sala et al. 2004: 241).

\section{CONCLUSIONES}

A modo de conclusión, resaltaremos los aspectos que, según nuestra opinión, definieron el comercio cartaginés durante la época bárquida. El rasgo que mejor determina las relaciones de intercambio a finales del siglo III a.C. con respecto a las fases precedentes es que la presencia de productos cartagineses no supuso una ruptura radical ni de las relaciones de intercambio tradicionales de los distintos puertos de la península ibérica con Cartago ni del modo en que éstas se desarrollaron.

Pero aunque la continuidad es el rasgo definitorio, la conquista de Iberia por parte de Amílcar Barca y, especialmente, la Segunda Guerra Romano-cartaginesa, introdujeron una serie de cambios importantes que, a largo plazo, cambiarían las relaciones comerciales en el Mediterráneo occidental. En este sentido, la necesidad de abastecer a los ejércitos romano y cartaginés de la zona comportó que la producción de alimentos y otros bienes imprescindibles creciera de manera inusitada, lo que forzosamente propició un aumento de las relaciones comerciales y su volumen tal como manifiesta la gran dispersión de productos anfóricos cartagineses documentados en todo el Mediterráneo y, en especial, en la península ibérica. De hecho, la relación entre el abastecimiento militar y la comercialización de productos alimenticios norteafricanos es tan directa, que en la mayoría de zonas donde se ha podido documentar una concentración de este conjunto anfórico, esta presencia puede vincularse con alguno de los frentes de la Segunda Guerra Romano-cartaginesa. El abastecimiento de colonos y soldados provocó la creación de un sistema para favorecer el comercio, tanto terrestre como marítimo, en el que se incluía una compleja red de fortificaciones, la fundación de colonias de veteranos, el uso de la flota como medio de protección de las principales vías de comunicación y la incentivación del comercio por medio de la creación de infraestructuras portuarias y disposiciones legales.

Todo ello provocará el nacimiento de un comercio de tipo imperial que, sin llegar a ser mayoritario, como demuestran las cargas heterogéneas de los pecios y el consecuente predominio del comercio redistributivo, alcanzó una representación significativa en los principales puertos del Mediterráneo central y, sobre todo, occidental, incluso llegando a ser mayoritario en las nuevas colonias de Cartago y en sus asentamientos de veteranos. Aunque aún debemos definir mucho mejor el papel que las grandes familias dirigentes de la política de Cartago jugaron en las actividades comerciales, es innegable su participación en las mismas, máxime cuando la expansión cartaginesa y el posterior conflicto con Roma las hacía tan lucrativas. La presencia de un repertorio formal de ánforas variado podría ser un reflejo de la lucha por la supremacía económica y política de estas familias, sobre la cual las fuentes clásicas nos han legado algún indicio (Pol. 9.11.1-2; Diod. 25.8). También la producción agropecuaria y su posterior comercialización serían importantes fuentes de conflicto por la hegemonía económica: de hecho, sabemos por Tito Livio (33.18.1) que los bárquidas poseían una gran hacienda agrícola en territorio líbico entre Acholla (Ras Botria, Túnez) y Thapsus (Bekalta, Túnez) y que, por lo tanto, estuvieron implicados directamente en la explotación territorial y la posterior distribución de los excedentes, de las que se beneficiarían enormemente.

La derrota cartaginesa en la guerra y el consecuente ostracismo al que fueron sometidos los miembros supervivientes de la familia bárquida evidencian esta dura rivalidad entre unas agrupaciones familiares que contaban con unos medios análogos, pero distintas vías sociales y políticas para mantenerlos y aumentarlos.

\section{Agradecimientos}

Una parte importante de los resultados presentados en este artículo son el resultado de una estancia de investigación desarrollada en marzo de 2014 en la Maison Archéologie et Ethnologie, René-Ginouvès - UMR 7041 ARScAn de la Universidad de Paris X - Nanterre bajo la supervisión del Profesor Pierre Rouillard que fue financiada por el grupo de Investigación HUM-741 "El Legado de la Antigüedad" dirigido por José Luis López Castro 


\section{BIBLIOGRAFÍA}

Abelli, L. (2011): Il Ruolo di Pantelleria nelle rotte del Canale di Sicilia dalla preistoria al tardoantico. Tesis doctoral, Universidad di Sassari, inédita. http:// eprints.uniss.it/4910/

Alonso-Nuñez, J. M. (1989): "Reflexiones sobre el imperialismo romano en Hispania", en Problemas de la Hispania Republicana, Studia histórica 7: 7-10. Salamanca. http://dialnet.unirioja.es/servlet/ articulo?codigo $=106301$

Aquilué, X.; Castanyer, P.; Santos, M. y Tremoleda, J. (2004): 'L'evolució dels contextos de materials amfòrics en la Palaia Polis d'Empòrion entre els segles VI i II a.C.", en La circulació d'àmfores al Mediterrani Occidental durant la Protohistòria (segles VIII - III a.C.): aspectes quantitatius $i$ anàlisi de continguts, II Reunió Internacional d'Arqueologia de Calafell, Arqueomediterrània 8: 165-183. Barcelona, Departament de Prehistòria, Història Antiga i Arqueologia de la Universitat de Barcelona.

Asensio, D. y Martín i Menéndez, A. (1999): “El derelicte de Bon Capó (l'Ametlla de Mar): l'inici de l'expansió de vi itàlic a la Península Ibèrica", en $E l$ vi a l'Antiguitat. Economia, producció $i$ comerç al Mediterrani Occidental, II Col-loqui Internacional d'Arqueologia Romana, Monografies Badalonines 14: 135-150. Barcelona, Museu de Badalona.

Barceló, P. (1996): "Reflexiones en torno al establecimiento del poderío cartaginés en Hispania". Millars, Espai i Història 19: 5-19. http://www.raco. cat/index.php/Millars/article/view/129960

Barrionuevo, F. J.; Ruiz Mata, D. y Pérez, C. J. (1999): "Fortificaciones de casernas del Castillo de Doña Blanca (El Puerto de Santa María, Cádiz)", en XXIV Congreso Nacional de Arqueología, Vol. III: 115123. Cartagena, Gobierno de la Región de Murcia e Instituto de Patrimonio Histórico.

Bendala Galán, M. (2003): "De Iberia in Hispaniam. El fenómeno urbano", en De Iberia in Hispaniam. La adaptación de las sociedades ibéricas a los modelos romanos: 15-35. Murcia, Universidad de Alicante.

Bendala Galán, M. (2013): “Aníbal y los Barca: el proyecto político cartaginés de Hispania", en M. Bendala Galán (ed.), Fragor Hannibalis. Aníbal en Hispania: 46-81. Madrid, Comunidad de Madrid.

Benoit, F. (1961): Fouilles sous-marines. L'épave du Grand Congloué à Marseille. París, Centre National de la Recherche Scientifique.

Berrocal, M. C. (1998): "Instalaciones portuarias en Carthago Nova: La evidencia arqueológica", en
Puertos Antiguos y Comercio marítimo, III Jornadas de Arqueología Subacuática: 101-114. Valencia, Universitat de València.

Blázquez, J. M. (2005): "La política Bárquida en la Península Ibérica", en Atti del V Congresso Internazionale di Studi Fenicie e Punici, vol. III: 13311342. Palermo, Università di Palermo.

Blázquez, J. M. (2012): "La herencia de Amílcar Barca (290-229 a.C.) y de Asdrúbal (245-221 a.C.) a Aníbal (247-246-183 a.C.): La Segunda Guerra Púnica", en S. Remedios; F. Prados y J. Bermejo (eds.), Aníbal de Cartago. Historia y Mito: 27-43. Madrid, Ediciones Polifemo.

Blázquez, J. M. y García-Gelabert, M. P. (1991): "Los bárquidas en la Península Ibérica", en Atti del II Congresso Internazionale di Studi Fenici e Punici, vol. II: 27-50. Roma, Consiglio Nazionale delle Ricerche. http://www.cervantesvirtual.com/obra/losbrquidas-en-la-pennsula-ibrica-0/

Bonet, H.; Garibo, J.; Guérin, P.; Mata, C.; Valor, J. P. y Vives-Ferrándiz, J. (2004): "Las ánforas importadas de las comarcas centrales del País Valenciano", en La circulació d'àmfores al Mediterrani Occidental durant la Protohistòria (segles VIII - III a.C.): aspectes quantitatius $i$ anàlisi de continguts, II Reunió Internacional d'Arqueologia de Calafell, Arqueomediterrània 8: 203-227. Barcelona, Departament de Prehistòria, Història Antiga i Arqueologia de la Universitat de Barcelona.

Bridoux, V. (2007): "Importations méditerranéenes du IIe s. av. n. è. en Maurétanie occidentale et hypothèses sur les voies d'acheminement", en Comercio, redistribución y fondeaderos. La navegación a vela en el Mediterráneo, V Jornadas Internacionales de Arqueología Subacuática: 419-434. Valencia, Universidad de Valencia.

Carretero Poblete, P. A. (2007): Agricultura y Comercio Púnico-Turdetano en el Bajo Guadalquivir. El inicio de las explotaciones oleícolas Peninsulares (siglos IV-II a.C.), BAR International Series 1703. Oxford, Archaeopress.

Cerdà, D. (1974): "Hallazgos submarinos y relaciones intermediterráneas", en Prehistoria y Arqueología de las Islas Baleares, VI Symposium Internacional de Prehistoria: 435-445. Barcelona, Universitat de Barcelona e Instituto de Arqueología y Prehistoria.

Cerdà, D. (1978): “Una nau cartaginesa a Cabrera". Fonaments 1: 89-105.

Cibecchini, F.; Capelli, C.; Fontaine, S. y Alfonsi, H. (2012): "Nouvelles considérations sur la cargaison de l'épave Sanguinaires A 
(Ajaccio, Corse du Sud)". Archaeonautica 17: 31-69. https://www.academia.edu/2969889/ NOUVELLES_CONSID\%C3\%89RATIONS SUR LA CARGAISON DE L \%C3\%89PAVE SANGUINAIRES_A_AJACCIO_CORSE_DU_ SUD

Corzo, R. (1978): "La segunda guerra púnica en la Bética”. Habis 6: 213-240. http://dialnet.unirioja.es/ servlet/articulo?codigo $=653597$

Costa, B. (2000): “'Ybsm (Ibiza) en la Segunda Guerra Púnica", en La Segunda Guerra Púnica en Iberia, XIII Jornadas de Arqueología fenicio-púnica: 63-115. Ibiza, Museu Arqueològic d'Eivissa i Formentera.

Descat, R. (1994): "La cité grécque et les échanges. Un retour à Hasebroek", en Économie Antique. Les échanges dans l'Antiquité: le rôle de l'État, Entretiens d'Archéologie et d'Histoire 1:11-30. Tolosa, Musée archéologique départemental de Saint-Bertrand-de-Comminges.

Docter, R. (1994): "Karthagische Amphoren aus Toscanos". Madrider Mitteilungen 35: 123-139. http:// www.researchgate.net/publication/254797026 Karthagische_Amphoren_aus_Toscanos

Domínguez Pérez, J. C. (2006): Gadir y los fenicios occidentales federados V-III AC: dialéctica aplicada al territorio productivo turdetano, BAR International Series 1513. Oxford, Archaeopress.

Ferrer Albelda, E. (1998): "Suplemento al mapa paleoetnológico de la Península Ibérica: los Púnicos en Iberia". Rivista di Studi Fenici 26, 1: 31-54.

Ferrer Maestro, J. J. (2004): “Gastos de guerra y administración de bienes de dominio público en la gestión púnica de España”, en El mundo púnico: religión, antropología y cultura material, Actas del II Congreso Internacional del Mundo Púnico, Estudios Orientales 5-6: 439-449. Murcia, Universidad de Murcia. http://dialnet.unirioja.es/servlet/ articulo?codigo $=1355794$

Finley, M. I. (1986): La economía de la Antigüedad. México [ $1^{\mathrm{a}}$ edición 1973], Fondo de Cultura Económica.

Fortea, J. y Bernier, J. (1970): Recintos y fortificaciones ibéricas en la Bética, Memorias del Seminario de Prehistoria y Arqueología 2. Salamanca, Universidad de Salamanca.

García Riaza, E. y Sánchez León, M. L. (2000): Roma y la municipalización de las Baleares. Palma, Edicions UIB.

González Wagner, C. (1989): “The Carthaginians in Ancient Spain: from Administrative Trade to Territorial
Anexation", en Punic Wars, Studia Phoenicia 10: 145-156. Lovaina, Peeters Publishers.

González Wagner, C. (1999): "Los Bárquidas y la conquista de la Península Ibérica”. Gerión 17: 263-294. http://dialnet.unirioja.es/servlet/articulo? codigo= 101336

Guerrero, V. M.; Miró, J. y Ramón, J. (1989): “El pecio de Binisafúller (Menorca), un mercante púnico del siglo III a.C.". Meloussa 2: 9-30.

Guerrero, V. M.; Miró, J. y Ramón, J. (1991): “L'épave de Binisafuller (Minorque), un bateau de commerce punique du III" siècle av. J.-C.", en Punic Wars, Studia Phoenicia 10: 115-125. Lovaina.

Gutiérrez, L.; López Castro, J. L. y Martínez Hahnmüller, V. (e.p.): "Evidencias sobre la presencia cartaginesa en Giribaile (España)", en VIII Congresso Internazionale di Studi Fenici e Punici, Sassari, Università di Sassari.

Hopper, R. J. (1979): Trade and Industry in Classical Greece. Londres, Thames and Hudson.

Hurst, H. (1983): "The War Harbour of Carthage", en Atti del I Congresso Internazionale di Studi Fenici e Punici: 603-610. Roma, Consiglio Nazionale delle Ricerche e Istituto per la Civiltà Fenicia e Punica.

López Castro, J. L. (2000a): "Las ciudades fenicias occidentales durante la Segunda Guerra romanocartaginesa", en La Segunda Guerra Púnica en Iberia, XIII Jornadas de Arqueología fenicio-púnica: 51-61. Ibiza, Museu Arqueològic d'Eivissa i Formentera.

López Castro, J. L. (2000b): “Carthage and Mediterranean Trade in the Far West". Rivista di Studi Punici 1: 123-144.

López Castro, J. L. (2003): "La formación de las ciudades fenicias occidentales". Byrsa 2: 69-120.

Loreto, L. (1995): La grande insurrezione libica contro Cartagine del 241-237 a.C. Una storia politica e militare, Collection de l'École Française de Rome 211. Roma, École française de Rome.

Manfredi, L. I. (2003): "La politica amministrativa di Cartagine in Africa". Atti della Accademia Nazionale dei Lincei 16, 2: 324-532.

Maraoui Telmini, B. y Bouhlel, S. (2011): "Petrographic and mineralogy characterisation of local punic plane ware from Carthage and Utica", en Ceramics of the Phoenician-Punic World: Collected Essays, Ancient Near Eastern Studies Supplement 36: $327-$ 347. Lovaina, París y Walpone, Isd.

Marín, C. (1997-1998): “Un modelo estratigráfico de la Cartagena púnica: la muralla de Qart-Hadast". Anales de Prehistoria y Arqueología de Murcia 
13-14: 121-139. http://revistas.um.es/apa/article/ view/62781

Martín Camino, M. y Belmonte, J. A. (1993): “La muralla púnica de Cartagena: valoración arqueológica y análisis epigráfico de sus materiales". Aula Orientalis 11: 161-171. http://www.aulaorientalis.org/AuOr\%20escaneado/AuOr\%2011-1993/ N_2/4.pdf

Martín Camino, M. y Roldán Bernal, B. (1994): “Un tipo de ánfora púnica centromediterránea en occidente durante época bárquida: Melin/Drappier-3", en El mundo púnico. Historia, Sociedad y Cultura: 465-475. Murcia, Editora Regional de Murcia.

Martínez Hahnmüller, V. (2011): La política social y económica de los Bárquidas en la Península Ibérica. Tesis Doctoral inédita. Almería, Universidad de Almería.

Martínez Hahnmüller, V. (2012): Baria II. La conquista romana de Baria. Almería, Universidad de Almería.

Más, J. (1998): "Portus Carthaginiensis. Simbiosis de un emporio y una gran base militar", en Puertos Antiguos y Comercio maritimo, III Jornadas de Arqueología Subacuática: 79-97. Valencia, Universidad de Valencia.

Mederos, A. y Ruiz Cabrero, L. A. (2004): “El pecio del Bajo de la Campana (Murcia, España) y el comercio del marfil norteafricano". Zephyrus 57: 263281. http://revistas.usal.es/index.php/0514-7336/ article/view/5407

Moret, P. (1990): "Fortins, "tours d'Hannibal" et fermes fortifiées dans le monde ibérique". Mélanges de la Casa de Velázquez 26, 1: 5-43. http://www.persee. $\mathrm{fr} / \mathrm{doc} / \mathrm{casa}$ 0076-230x_1990_num_26_1_2558

Moret, P. (1996): Les fortifications ibériques de la fin de l'âge du Bronze à la conquête romaine, Collection de la Casa de Velázquez 56. Madrid, Casa de Velázquez.

Noguera, J. M.; Madrid, M. J. y Velasco, V. (20112012): "Novedades sobre la arx Hasdrubalis de Qart Hadasht (Cartagena): nuevas evidencias arqueológicas de la muralla púnica". Cuadernos de Prehistoria y Arqueología de la UAM 37-38: 479-508. https://repositorio.uam.es/handle/10486/12462

Olcina, M.; Guilabert, A. P. y Tendero, E. (2010): “Lectura púnica del Tossal de Manises (Alicante)", en Los Púnicos de Iberia: Proyectos, Revisiones, Sintesis, Mainake 32, 1: 229-249. http://dialnet.unirioja.es/servlet/articulo? codigo $=3643433$

Parker, A. J. (1992): Ancient Shipwrecks of the Mediterranean \& Roman Provinces, BAR International Series 580. Oxford, Archaeopress.
Pérez Vilatela, L. (1991): "Sagunto, de Estado soberano a presidio cartaginés". Arse 25: 9-22.

Polanyi, K. (1994): El sustento del hombre. Madrid [1 ${ }^{\mathrm{a}}$ edición 1977], Mondadori.

Prados, F. (2007): “La presencia neopúnica en la Alta Andalucía: a propósito de algunos referentes arquitectónicos y culturales de época bárquida (237-205 a.C.)". Gerión 25: 83-110. http://dialnet.unirioja.es/ servlet/articulo?codigo $=2529625$

Principal-Ponce, J. (1998): Las importaciones de vajilla fina de barniz negro en la Cataluña sur y occidental durante el siglo III a.C. Comercio y dinámica de adquisición en las sociedades indígenas, BAR International Series 729. Oxford, Archaeopress.

Py, M.; Adroher, A. M. y Sanchez, C. (2001): Corpus des céramiques de l'âge du Fer de Lattes, Lattara 14, vol. 1. Lattes, Editions de l'Association pour la recherche archéologique en Languedoc oriental.

Ramón, J. (1995): Las ánforas fenicio-púnicas del Mediterráneo Central y Occidental, Instrumenta 2. Barcelona, Universitat de Barcelona.

Ramón, J. (2006): “Comercio y presencia cartaginesa en el extremo occidente y atlántico antes de las Guerras Púnicas", en Economía y finanzas en el mundo fenicio-púnico de Occidente, XX Jornadas de Arqueología fenicio-púnica: 69-107. Ibiza, Museu Arqueològic d'Eivissa i Formentera.

Ramón, J. (2008): “El comercio y el factor cartaginés en el Mediterráneo occidental y el Atlántico en época arcaica", en Los fenicios y el Atlántico, IV Coloquio del CEFYP: 233-258. Santa Cruz de Tenerife, Universidad Complutense y Centro de Estudios Fenicios y Púnicos.

Reed, C. M. (2004): Maritime traders in ancient Greek world. Cambridge y Nueva York, Cambridge University Press.

Roldán Gómez, L.; Bendala, M.; Blánquez, J. y Martínez Lillo, S. (2006): Estudio histórico-arqueológico de la ciudad de Carteia (San Roque, Cádiz). Sevilla, Consejería de Cultura de la Junta de Andalucía.

Roldán Hervás, J. M. (1997): "Romanos y cartagineses en la Península Ibérica. La Segunda Guerra Púnica”, en La Guerra en la Antigüedad. Una aproximación al origen de los ejércitos en Hispania: 271-279. Madrid, Ministerio de Defensa, Ministerio de Cultura e Instituto del Patrimonio Histórico Español.

Ruiz Cabrero, L. A. (2009): "Sociedad, Jerarquía y Clases Sociales de Cartago", en Instituciones, Demos y 
ejército en Cartago, XXIII Jornadas de Arqueología Fenicio-púnica: 7-73. Ibiza, Museu Arqueològic d'Eivissa i Formentera.

Sáez, A. M.; Montero, R. y Toboso, E. J. (2004): “Un antecedente centro-mediterráneo al complejo alfarero púnico de Torre Alta (San Fernando, Cádiz)", en Las industrias alfareras y conserveras fenicio-púnicas de la Bahía de Cádiz, XVI Encuentros de Historia y Arqueología: 201-236. Córdoba, Publicaciones Obra Social y Cultural CajaSur.
Sala, F.; Grau, I.; Olcina, M. y Moltó, J. (2004): "El comerç d'àmfores en época protohistórica ibérica a les terres de la Contestània", en La circulació d'àmfores al Mediterrani Occidental durant la Protohistòria (segles VIII-III a.C.): aspectes quantitatius $i$ anàlisi de continguts, II Reunió Internacional d'Arqueologia de Calafell, Arqueomediterrània 8: 229-251. Barcelona, Departament de Prehistòria, Història Antiga i Arqueologia de la Universitat de Barcelona.

Scardigli, B. (1991): I trattati romano-cartaginesi. Pisa, Scuola Normale Superiore. 